\title{
JOGLARIA I ACTIVITAT DRAMÀTICA
}

\author{
Francesc Massip \\ Universitat Rovira i Virgili \\ francesc.massip@urv.cat
}

\section{Resum}

Anàlisi de la rehabilitació de l'ofici joglaresc a cavall dels segles XII-XIII. Classificació de les distintes especialitats joglaresques segons la iconografia i els textos que normalment les descriuen per prohibir-les, amb algunes excepcions. Intent de dilucidació de l'escenari que devia ser habitual en les exhibicions joglaresques d'especificitat dramàtica.

\section{Paraules clau}

Joglar, iconografia, espai escènic joglaresc.

\begin{abstract}
Analysis of the rehabilitation of the minstrels in the I2th and 13 th centuries. Classification of the different types of minstrel techniques according to the iconography and textual sources, that — apart from some exceptions — tend to be prohibitive. Attempt to analyse the areas that hosted jester drama performances.
\end{abstract}

\section{Keywords}

Minstrels, iconography, jester's area of performance.

\section{5}

Recentment, Silvère Menegaldo afirmava que "en l'estat actual de la recerca, no es posseeix cap testimoniatge indiscutible referent a les activitats teatrals dels joglars o dels ministrils als segles XII i XIII". ${ }^{\text {. }}$

És cert que tenim diversa documentació per escrit i en imatges sobre la polifacètica tasca espectacular dels joglars en els diversos àmbits de la vida medieval, però només una projecció crítica ens permet vincular alguna de les activitats documentades amb una pràctica veritablement dramàtica. Tot fa pensar que des del segle XII va existir una activitat teatral profana, no sempre excepcional, sens dubte en mans de la joglaria.

I "Les jongleurs et le théâtre en France au XIII" siècle, leurs activités et leur répertoire", Romania, I28, I-2 (20IO), pp. 46-97. 
Com explica la professora Pietrini, la majoria de testimonis de l'activitat joglaresca emanen de les reiterades condemnes eclesiàstiques. ${ }^{2}$ [Fig. I] Guillem d'Auvèrnia situava els joglars entre els éssers demoníacs i Honori d'Autum els considerava "ministres de Satanàs". ${ }^{3}$ La duresa del blasme catòlic contra el joglar radicava en el fet que eren portadors d'unes tècniques i unes habilitats basades en el cos i la seva expressió, i ja sabem l'estranya relació que el cristianisme ha mantingut sempre amb la corporeïtat, amb tota mena de tabús, repressions i ocultacions. Les invectives contra el joglar se centraven sobretot com a expositor de sí mateix, com a ser que fa espectacle del seu cos. ${ }^{4}$ Per això se l'acusa, com a la prostituta, de fer del seu cos (un do de Déu) objecte de mercadeig i d'exhibició. ${ }^{5}$ A més a més, com a professional del joc, com a home que juga (joculator), és acusat de dur a terme una labor improductiva, sense utilitat social, marginat de l'ordre social establert; i que, a sobre, fa perdre el temps als homes i els desvia de l'atenció deguda a Déu. També li toca rebre a aquell públic que ofereix dons i diners als joglars, quan l'única destinatària legítima de l'almoina era l'Església ${ }^{6}$.

Però aquestes consideracions comencen a posar-se en qüestió ja al tombant del segle XII, quan el joglar s'ha convertit en la viva veu de la cultura medieval i en el personatge amb major mobilitat geogràfica i social de l'edat mitjana, gràcies a la universalitat de les seves tècniques espectaculars (mímica, dansa, música, acrobàcia, prestidigitació), que feien particularment exportables els seus productes espectaculars. Però també com a hàbils portadors de noves, contadors d'històries, difusors d'idees i missatges al servei de trobadors, senyors eclesiàstics o laics, com a heralds de prínceps o ambaixadors de reis, homes d'humor, en fi, molt celebrats, gràcies al domini de l'ús de la paraula, a la seva capacitat mnemotècnica, habilitat retòrica i fluïda eloqüència, competents com eren en les tècniques poètiques i expressives més adequades.

[Fig. 2] Tot plegat incideix en la dignificació de l'ofici joglaresc, a començar per les consideracions del teòleg de Salisbury Thomas Chobham (c.II6O-I235), autor d'una Suma Confessorum, un manual per a confessors escrit cap a 1215 on

2 S. Pietrini, I Giullari nell'immaginario medievale, Roma, 20II, pp. 40-4I.

3 "D[iscipulus].- Habent spem ioculatores? M[agister]. - Nullam. Tota intentione ministri sunt Satanae" (Honorius Augustodunensis, PL i72, p. II48).

4 L. Allegri, L'arte e il mestiere. L'attore teatrale dell'antichità ad oggi, Roma, 2005, pp. 53-65.

5 "Pauperes, debiles, ceci, claudi, manci, loripedes, vel alias corpore deformati, kalones, joculatores, saltatores, fidicines, tibicines, lyricines, tubicines, cornicines, hystriones, gesticulatores, nebulones, parasiti, scurre, ribaldi, buflarlatores, adulatores, carciones, proditores, detractores, susurrones, filii perditionis apostate, lotrices, publice mulieres quasi syrenes" (Konrad von Mure [Cuonrado], Summa de Arte prosandi (s. XIII), apud Pietrini, I Giullari..., p. 4In).

6 C. Casagrande i S. Vecchio, "Linterdizione del giullare nel vocabolario clericale del xir e del xiII secolo”, a J. Drumbl ed., Il teatro medievale, Bologna, 1989, pp. 317-368 (pp. 324-325 de referència). 
aconsella per començar que, en el cas que anés un histrió a confessar-se, només se'l pot absoldre si abandona completament l'ofici, excepte un determinat gènere d'histrions "que s'anomenen joglars, que canten amb els seus instruments les gestes dels prínceps i les vides dels sants, i procuren solaç als homes bé quan són malalts, bé quan pateixen afliccions". ${ }^{7}$ Només aquests mereixen l'absolució perquè realitzen “coses útils per recrear els homes”. Finalment s'atorgava al joglar una funció social de la qual havia estat desposseït fins aleshores. [Fig. 3] Una importantíssima rehabilitació que fa oficial, em sembla que per primera vegada, Jaume in de Mallorca (no pas II com deia Menéndez Pidal) en les seves Lleis Palatines (compilades el I337) quan en la rúbrica De Mimus seu Ioculatoribus, estableix que:

en les cases dels prínceps hi pot haver lícitament mims i joglars. Puix el seu ofici dóna aquella alegria que els prínceps deuen desitjar moltíssim i deuen mantenir honestament, a fi que, mitjançant aquella, allunyen la tristesa i malhumor, i en tot es mostren amables. ${ }^{8}$

Gran apotegma: la joglaria (o determinada joglaria) s'ha convertit en un menester d'estat, per la saludable letícia que provoca en els dirigents, cosa que collabora al bon govern (com avui en dia el "Polònia”, per entendre'ns). Serà per això que el segle XIV experimenta una inflexió en l'anomenada teatralitat medieval.

\section{UNA BIGARRADA TIPOLOGIA DE L'ENTRETENIMENT}

A la Península Ibèrica les operacions de rehabilitació de l'ofici del joglar que havia perfilat Chobham es tradueixen i s'amplien al Libro de las Confesiones de Martín Pérez, escrit entre I3I3 i I3I7 segurament a Salamanca i dirigit als "clérigos menguados de sçiençia” per tal que puguin confessar i confegir sermons amb les eines adequades. Pérez, parafrasejant Chobham, distingeix entre la diversitat d'especialitats atribuïdes als joglars o histrions i, tot blasmant-les, en fa una detallada taxonomia. [Fig. 4] Recordem que Chobham distingia tres tipus d'entretenidors. En

7 "Sunt autem alii qui dicuntur joculatores, qui cantant gesta principum et vitam sanctorum, et faciunt solatia hominibus vel in aegritudinibus suis vel in angustiis". Cf. E. K. Chambers, The Medieval Stage, London, 1903, II, pp. 262-263.

8 "In domibus principum ut tradit antiquitas, mimi seu ioculatores licite possunt esse; nam eorum officium tribuit laetitiam quam principes debent summe appetere et cum honestate servare ut per eam, tristitiam et iram abiciant, et omnibus se exhibeant gratiores. Quapropter volumus et ordinamus quod in nostra curia mimi debeant esse quinque, quorum duo sint tubicinatores et tertius sit tabelerius...”, Jaume III, rei de Mallorca, Leges Palatinae (I337), ed. L. PÉrez Martínez, vol. I, Palma, I99I, p. 90 (traducció) i p. I47 (original llatí). 
primer lloc els que transfiguren el seu cos amb postures (saltus) i comportaments deshonestos, bé despullant-se de forma indecorosa, bé revestint-se amb màscares indecents. [Fig. 5] Pérez ho adapta amb aquestes paraules, parlant dels

estriones e moharraches... que se transforman en otras semejanças, vestiendo caras e otras vestiduras en semejanças de diablos e de bestias, e desnudan sus cuerpos e entíznanse e fazen en sý torpes saltos e torpes gestos e muy torpes e suzias joglerías... por plazentear a los omnes e por ganar algo,

\section{i concretament menciona a}

los que fazen los çaharrones por las villas e por los mercados, e detienen los omnes en vanidades.

Cal dir que "zaharrón" és un dels molts termes de caire espectacular que han passat a les llengües ibèriques des de l'àrab, en aquest cas de sahhar que val per 'disfressa còmica'. ${ }^{9}$ Encara avui en dia designa una figura del folklore rural castellà i astur-lleonès: el zaharrón, ${ }^{\mathrm{I}}{ }^{\mathrm{O}}$ zafarrón, zangarrón, zamarrón, tafarrón, mazarrón o cigarrón. Solen caracteritzar-se per anar emmascarats amb caretes animalístiques o diabòliques (banyes), vestits bigarrats i esquellots a la cintura, solen fustigar la gent amb fuets tous o bufetes de porc i solen vincular-se a les festes d'hivern. Per tant, una figura de la festa agrària coincident amb la descripció de Pérez, amb una elevada capacitat de transgressió perquè, de segur, també actuava en moments d'inversió ritual i permissió (llicències hivernals i Carnestoltes), i que acomplia una funció ritual d'obtenir una bona anyada agrícola i uns bons auguris, cosa que també disgusta a Pérez [Fig. 6]:

Mas ay otra cosa que es peor: que algunos son venidos a tan grand ceguedat de las sus almas que cuydan e dizen que por el uso de los arcos e de las palas e de los çaharrones e de otras tales vanidades vienen los buenos tenporales e los buenos años.

Però anem a pams, perquè en aquesta primera classificació apareix clarament la condició interpretativa o actoral de certs joglars. Transformar el seu aspecte, transfigurant el cos, vol dir prendre l'aparença d'un personatge, reproduint els gestos impúdics i els comportaments indecents que el personatge de ficció acomplia en les accions escèniques que duria a terme l'histrió. La conversió del joglar en

9 També és terme àrab Moharrache (i els seus derivats: homarrache i mamarracho) que ve de muharrijun i que encara avui a Damasc designa el còmic; o Matatxi derivat de mutauajjihin o 'persona emmascarada'.

Io María Moliner diu que 'zaharrón' és paraula antiga i que era "Persona que, con un disfraz grotesco, hacía cosas para divertir a la gente". 
personatge la faria bé posant-se una màscara, una careta animalística o diabòlica, bé despullant-se (perquè l'argument ho exigiria) i embetumant-se la pell. [Fig. 7] Chobham, quan discrimina els únics joglars que es poden salvar, els contraposa als que abans ha condemnat: els "saltatores et saltatrices", això és, els mims, els que interpreten (ludunt) en quadres o escenes deshonestes (in imaginibus inhonestis) i fan aparèixer una mena de fantasmes per encantament o altrament, ${ }^{\text {II }}$ que potser vol dir que recreen personatges, ${ }^{12}$ tot i que Martín Pérez ho adapta altrament, com si parles de mags o de prestidigitadors:

Otros fazen algunas encantaçiones, como fazen algunos pareşer con engaño que mudan algunas cosas en culebras o en ranas o dados o en otras tales cosas que son contra natura e sobre natura. E estas todas cosas fazen ellos engańosamente escarnesçiendo los ojos de los locos que se pagan de ver vanidades...

[Fig. 8] Tornant a la màscara, també Etienne de Bourbon, cap a I260, caracteritzava els joglars per aquest element característic de teatralitat, fos careta o maquillatge. Ho fa en comparar les dones velles que "es pinten i s'adornen com a ídols, de manera que sembla que vagin emmascarades, com aquests joglars que porten la cara pintada i que en francès s'anomenen 'artificia' (artificis), amb els quals interpreten i se'n riuen de la gent". ${ }^{13}$

Artifisi, en el sentit de màscara, ja apareixia, en occità, al sirventes-ensenhamen de Girauz de Calanson al joglar Fadet, al qual el trobador li diu que tindrà una barba de color roig amb la que es podrà disfressar en tal guisa que podrà ben espantar, i que tindrà una màscara que si sap renillar bé podrà semblar un cavall, mentre li recomana que faci saltar el gos sobre un bastó i que l'obligui a sostenir-se sobre les dues potes. ${ }^{14}$

II "Sunt autem alii qui dicuntur joculatores, qui cantant gesta principum et vitam sanctorum, et faciunt solatia hominibus vel in aegritudinibus suis vel in angustiis, et non faciunt innumeras [inimicas] turpitudines sicut faciunt saltatores et saltatrices et alii qui ludunt in ymaginibus inhonestis et faciunt videri quasi quaedam fantasmata per incantationes vel alio modo..." (CHAMBERTs, cit.).

I2 M. Rousse, La scène et les tréteaux. Le théâtre de la farce au Moyen Âge, Orléans, 2004, p. I63.

I3 "Contra illas que, cum sint vetule, quasi ydola se pingunt et ornant, ut videantur esse larvate, ad similitudinem illorum joculatorum qui ferunt facies depictas, que dicuntur artificia gallice, cum quibus ludunt et homines deludunt" (ETIEnNe De Bourbon, c. I260).

I4 "IX. Barba-coia / Auras roia / Don ti poiras totz revestir; / Pel garnimen / As qe.i apen,/ Ben poiras fol esferezir. / X. Artifisi, / Car siguisi, / Auras gran(s), s'ab el saps endir; / Tom de goso / Sobr'un basto / E faio l'en dos pes sostenir" (F. РіRot, Recherches sur les connaissances littéraires des troubadours occitans et catalans des XII et XIII siècles. Les "sirventes-ensenhamens" de Guerau de Cabrera, Guiraut de Calanson et Bertrand de París, Memorias de la Real Academia de Buenas Letras de Barcelona, vol. I4 (1972), pp. 563-595). 
En aquestes màscares que permetien al joglar incorporar una tipologia de personatges grotesca, destinats a provocar el riure i la diversió, prendrien peu les de la futura commedia dell'arte que, evidentment, no podia sorgir del no-res.

També Pérez, seguint Chobham, fa una clara distinció entre "los joglares que cantan cantares de los santos e de las faziendas o de las vidas de los reyes o de los príncipes e non cantan otros cantares locos que mueven a los omes a amor mundanal e cantan en lugares honestos" i aquests considera que poden viure del seu ofici i ser bons cristians, i els discrimina dels "joglares que cantan cantares suzios e de caçorría e otros cantares vanos de amor que mueven a los oÿdores a luxuria e a pecado”. És a dir, discrimina clarament els únics joglars que eviten la condemna gràcies a la propietat dels arguments que interpreten, mentre aprofita per carregar contra l'altra espècie de joglaria, ben antiga i se suposa que molt exitosa, dedicada a distreure la gent amb relats d'aventures amatòries, embolics eròtics i d'argument sexual, qui sap si d'un gènere semblant al repertori de peces que representava Pere Çahat "magister ludis amoris", a qui, el I338, Pere III el Cerimoniós atorga un salconduit, a ell i la seva "societas" (companyia actoral?) que l'autoritzava a actuar en els seus dominis. ${ }^{\text {I5 }}$

[Fig. 9] Bastava que un joglar es transvestís de dona per ser qualificat d'indecent pels moralistes de l'època. Ja Isidor de Sevilla a les seves Etimologies definia els histrions com aquells

que en els espectacles es presentaven amb la cara coberta, amb el rostre pintat ara de color blau, ara de roig (minium) i altres pigments, mostrant caretes tenyides de guix i de colors diversos, i fins i tot amb el coll i les mans de greda (argila blanquinosa), i així, mitjançant el color, esdevenir un personatge i enganyar el poble durant la representació (ludis). Ara es presenten com a homes, ara com a dones; ara apareixen calbs, ara es pentinen la cabellera; tan aviat es mostren com a vellets que com a donzelles, o sota una altra aparença qualsevol, canviant d'edat i sexe, de manera que enganyen el poble mentre representen el seu espectacle. ${ }^{16}$

L'obsessió contra la ficció actoral, contra l'intèrpret en la seva condició d'“habitador d'un ser que no s'és", ${ }^{17}$ serà recurrent durant tota l'Edat Mitjana.

Pérez parla també dels "llamados albardanes e han ofiçio malo... que viven por dezir mentiras e mucho mal de las lenguas", altrament dits "profazadores e dezido-

I5 Publico el document íntegre a F. Massip, "Huellas de Petrarca tras los espectáculos de entrada real en la confederación catalano-aragonesa (I397-I4I4)", Annali di Storia moderna e contemporanea I7 (20II [20I2]), pp. 7-32 (p. io de ref.). Vegeu també J. Romeu i Figueras, Teatre català antic, 3 vols., a cura de F. MAssip i P. VILA, Barcelona, 2004-2005, vol. III, p. I60.

I6 Isidoro de Sevilla, Etimologías, 2 vols. Madrid, i982, lib. X, p. II9.

I7 J. Duvignaud, Sociologia del Teatro: Ensayo sobre las sombras colectivas, México, 1966, p. II. 
res e trobadores de mal [que] suelen andar en las casas de los reyes e de los señores e dizen albardanerías e fazen escarnios e saben maldezir en manera de trobas" i es refereix concretament a "los pasafríos que andan por las villas e por los mercados diziendo mentiras e caçorrías e detienen los omnes con sus palabras e fázenles perder el tiempo espendiéndol en pecado". L'albardà seria un altra nomenclatura d'origen àrab, al-bardan, 'foll, que diu bestieses'. Per tant, aquesta tipologia joglaresca vindria caracteritzada per l'ús de la paraula, tot i que fos un verb transgressor, maldient, escarnidor, "cazurro" (una altra parauleta àrab que val per 'insociable'). [Fig. Io] Si el "zaharrón" era condemnable per l'aspecte, l'albardà ho era pel verb perillós, desvergonyit, obscè, no debades Covarrubias definia les "palabras caçurras" com les que "no se pueden pronunciar sin vergüença del que las dize y del que las oye, como nombrar el miembro genital (...) y otros vocablos semejantes" (Tesoro de la Lengua castellana, I6II). I, endemés, perquè amb les seves contalles malparleres feien perdre el temps a la bona gent, pecat imperdonable pels moralistes de l'època. Per això Pérez insisteix en la culpabilitat dels que fan d'espectadors i "que dan algo a los tales, en razón de los ofiçios que traen pagándose d'ellos, pierden cuanto les dan. E si quisieren saber quánto pecan oyan lo que dizen los santos: 'dar a los estriones non es otra cosa synon fazer sacrifiçio a los demonios'." Altre cop, doncs, l'assimilació dels professionals de l'espectacle amb la naturalesa demoníaca...

[Fig. II] També condemna Pérez als que, sense instruments

cantan quebrantando sus cuerpos, saltando e tornayrando e doblando sus cuerpos e torçiendo los ojos e las bocas o faziendo otros malos gestos e villanos de amor torpe e suzio... para ençender los omnes e las mugeres en amor malo. ${ }^{18}$

És a dir, blasma totes les especialitats joglaresques vinculades a l'habilitat corporal, [Fig. I2] particularment els contorsionistes i altres atletes del cos, com els que insistentment apareixen en capitells, miniatures i tota mena de figuracions plàstiques de l'època: el backbend (que corba l'esquena en sentit contrari a l'habitual), el pont, el cheststand o l'home serpent i el handstand (que enlaira les cames només recolzant en el pit o en les mans), el headseat o l'home granota (que s'asseu sobre el cap) i tota mena de possibles torsions i contorsions ${ }^{19}$.

Fixem-nos també en la reprovació gestual, novament vinculada a arguments eròtics que el moralista temia que provoquessin una mala influència en l'esperit de

I8 Totes les citacions de Martín Pérez procedeixen de J. Hernando, "Los moralistas frente a los espectáculos en la Edad Media”, dins El teatre durant l'Edat Mitjana i el Renaixement (Actes del I Simposi Internacional d'Història del Teatre, 1983), Barcelona, 1986, pp. 21-37.

I9 Vegeu també G. Strehly, L'acrobatie et les acrobates, París, I903, pp. IOO-IO3; agraeixo a Jordi Jané les equivalències en català d'aquestes contorsions. 
l'espectador. [Fig. I2 (a i b)] Ja el II77 Giraud de Cambria es mostrava escandalitzat per l'eloqüència gestual a què havien arribat els benedictins de Canterbury durant els períodes de silenci: no els era permès de parlar, però mantenien animades i distretes converses mitjançant els 359 signes codificats de què disposaven $i$ amb els quals feien anar mans, peus i dits a una velocitat inusitada: "tots desbordaven de gestos amb els dits, les mans o els braços i emetien siulets amb la boca enlloc de paraules, amb una frivolitat i una gosadia impúdica; i es removien tant que hom es veia transportat a les peces de teatre o entre els mims i els joglars". ${ }^{20}$

Uns gestos altament expressius, doncs, havien de caracteritzar el joglar intèrpret, les habilitats del qual serien tan ben imitades pels frares predicadors. [Fig. I4] És coneguda l'eficàcia retòrica de fra Vicent Ferrer, els sermons del qual insinuen també una gestualitat bigarrada i expressiva, i ja sabem que les seves prèdiques convocaven les masses a l'entorn del cadafal que les ciutats li paraven com si fos un histrió de qualitat, i despertava en l'audiència reaccions emocionades..$^{21}$ El Dietari del Capellà d'Anfós el Magnànim ens relata que en l'entrada de Joan II a València (I459) un frare, que comandava un espectacle de 8 Gomos, "parlà a la francesa ab moltes maneres de gests, molt altament e bé [...] que lo senyor rey e tots quants hi foren hagueren molt gran plaer de la manera de tan bella parleria del dit frare preïcador e del balar d'él e de sos companyons [...] que venien en manera de Gobos en lo hofici dels perayres". ${ }^{22}$

L'acció corporal, de matriu laica i popular, omnipresent en la plaça festiva, que serà un autèntic motor de teatralitat, només va poder accedir a la tradició històrica quan va ser assumida i reelaborada pels especialistes de la posada en text. Per aquest motiu, l'abundància de traces escrites referides al teatre litúrgic i d'argument religiós no ens ha de fer oblidar que hi ha hagué altres forces motrius d'espectacularitat segurament amb major impuls, com precisament l'activitat

20 "Tot etenim prior ad monachos servientes, et illi e contra ad mensas inferiores exenia ferendo, et hi quibus ferebantur gratias referendo, digitorum et manuum ac brachiorum gesticulationibus et sibilis ore pro sermonibus longe levius atque licentius quam deceret effluebant; ut quasi ad ludos scenicos aut inter histriones et joculatores sibi viderentur constitutus. Esset itaque magis ordini consonum et honestati verbis humanis cum modestia loqui, quam muta in hunc modum garrulitate signis et sibilis tam joculariter uti." (Giraldus Cambrensis, De rebus a se gestis, i..5, ed. J. S. Brewer, London, I86I, p. 5I). Apud J.-C. Sснмitт, La raison des gestes dans l'Occident médiéval, París, I990, p. 256.

2I Vegeu J. Fuster, "Loratòria de Sant Vicent Ferrer", Estudis d'Història Cultural, Castelló de la Plana, I992, pp. 53-6I.

22. M. Miralles, Crònica i dietari del capellà d'Alfons el Magnànim, ed. M. Rodrigo Lizondo, Universitat de València, 20II, pp. 260-26r. El document vacil.la entre la paraula "gomos" i "gobos", i ha de referir-se a les disfresses dels balls cortesans de "momos", reiteradament esmentats al Tirant, o altres comparses de màscares o farses dansades qui sap si relacionades amb l'italià "gobbo" (geperut). 
joglaresca i la festa agrària, però que no van comptar amb passeres sobre el riu de l'oblit de la història (això és, amb empremtes d'escriptura) fins bastant més tard.

Hi ha un decalatge abismal entre l'artífex del gest i el responsable de posar les paraules per escrit, en la mesura que l'un, per naturalesa, no deixa traces i l'altre per contra posseeix la competència especialitzada de l'escriptura, que en l'època només té el lletrat, el clericus, el qual tendeix a vehicular els arguments exemplars i edificants.

Però això començar a canviar al llarg del segle xiII quan apareixen els primers lletrats que són joglars d'ofici, que posen per escrit elaborades mostres de les seves experiències dramàtiques, que demostren partir d'una pràctica escènica precedent i que estan familiaritzats amb certes formes d'espectacle teatral.

I és que el renaixement urbà que experimenta Europa al llarg del segle XII, i particularment durant el xIII, va generar un refloriment de l'activitat dramàtica en la seva funció social, com a mitjà d'expressió privilegiat de l'urbs, entitat político-econòmica que estava prosperant decididament amb el comerç i l'artesanat. La cultura urbana, doncs, afavoreix l'eclosió d'un teatre urbà desvinculat del domini eclesiàstic i que ofereix fonamentalment una visió burlesca i crítica de la realitat, reflex d'un emergent esperit burgès.

Un cas paradigmàtic el representa Arràs, ciutat activa i puixant amb uns 20.000 habitants $\mathrm{i}$ amb uns 200 poetes de nom conegut, entre els quals Jean Bodel o Adam de la Halle, tots dos pertanyents a la Confrérie des Jongleurs et Bourgeois, una congregació que vehiculava el mecenatge cultural de la classe benestant amb ganes d' imitar les diversions de la noblesa feudal i que permetia crear a escriptors i joglars en un ambient de franca llibertat d'expressió. ${ }^{23}$

Jean Bodel (c. 1165-I209), joglar i trouvère, és autor del Jeu de Saint Nicolas, la primera obra firmada del teatre occidental en llengua vulgar. Malgrat l'argument religiós, la peça ja ha trencat radicalment amb el llatí i amb els lligams litúrgics, i se suposa que es va representar la vigília del sant de I200, el 5 de desembre. Tot plegat en honor a sant Nicolau que, segons la dita popular, "obre les festes amb clau" perquè encetava el dens cicle festiu d'hivern. En l'obra destaca el motiu còmico-burlesc en una llarga escena de taverna animada per uns pillards que han robat el tresor reial, cosa que obligarà el sant a intervenir. El realisme tavernari, amb l'argot dels lladregots, els insults, la beguda i el joc, fa que es produeixi un poderós contrast front al patetisme i l'aspecte sobrenatural de les altres escenes. El còmic es barreja amb el sublim i l'esperit sagrat amb la vida quotidiana.

A la mateixa ciutat d'Arras es va representar l'anònim Courtois d'Arras (abans de I228) que transporta la paràbola del fill pròdig al temps i al lloc de l'autor, i on retrobem el motiu de la taverna i el vi, amb la incorporació, però, de personatges

23 C. Mazouer, Le Theatre francais du moyen age, París, 1998, p. 90. 
femenins. Tot i ser dialogat, la presència de didascàlies en vers inserides en el dictat poètic, fa pensar que es tracti d'un monòleg joglaresc, car un mateix intèrpret podia fer els distints rols amb canvis de veu, de vestit o amb l'ajut de ninots. També un o dos joglars podrien haver interpretat la curiosa chantefable d'Aucassin et Nicolette, qualificat de "monòleg dramàtic" i de "mim", amb didascàlies que assenyalen l'alternança de distintes modalitats d'execució (prosa contada, versos cantats). I és que, com deia Zumthor, "el llenguatge narratiu no era menys 'teatral' que un altre, i no reclamava tècniques vocals i gestuals distintes". ${ }^{24}$

[Fig. I5] A mitjans del XIII apareixen altres testimonis d'una activitat clarament teatral entre joglars i ministrils. Al fabliau Le Vilain au buffet, s'associa els menestrils a activitats d'imitació expressiva com "fer el borratxo" o "fer el foll", amb una mímica, una gestualitat i un arrossegar la veu que permetés identificar l'ebrietat o la imbecilitat, com certament calia fer en les escenes de taverna dels mencionats textos dramàtics. Però a més es relacionen amb els qui diuen "la riote", "la genglerie" o "l'erberie", ${ }^{25}$ que han de fer referència a textos concrets o a tipologies textuals que s'han qualificat com a monòlegs dramàtics. És el cas, precisament, del Dit de l'Herberie ("el dir de l'herbolari"), escrit cap a I265 per Rutebeuf (I230-c.I290) un joglar i trouvere, que havia composat el Miracle de Théophile, i que en aquest Dit posa en escena el monòleg d'un venedor d'herbes remeieres amb una xerrera espirejant i engalipaire destinada a provocar la hilaritat tot parodiant els xarlatans de fira. [Fig. 16] Un comerciant de potingos i triagues que ja havia estat amplament desenvolupat en el drama sacre (el mercader apareix ja a l'Sponsus occità a finals de l'Xi i a Les Tres Maries de Vic de finals del XII i més endavant es fa acompanyar de la seva dona, l'apotecari, fills i criats) intervenció que, per força, s'havia de fer eco d'una realitat contingent no només al mercat quotidià, ans també en la seva estilització i paròdia espectacular. Rutebeuf presenta l'herbolari dirigint-se a l'audiència, convidant-la a seure en silenci per escoltar les excel-lències dels seus preparats guaridors de tot mal. S'anuncia com un metge format a Salern, l'escola mèdica més reputada de l'edat mitjana, exactament igual com farà cap a 1300 el Mercader de la Passion du Palatinus que, abans de proveir d'ungüent les Maries, proclama les virtuts dels seus beuratges d'herbes que permeten recobrar joventut, fer-se invisible per acomplir l'amor i fins i tot reviure els morts (vv. I864-1907).

L'herbolari de Rutebeuf desplega un ampli currículum que l'ha dut als països més exòtics reclamat per la seva destresa sanadora, i exhibeix tota varietat d'her-

24 P. Zumthor, La letra y la voz De la "literatura" medieval, Madrid, I989, p. 32I.

25 "L'uns menestrez a l'autre rueve / Faire son mestier tel com sot, / L'un fait l'ivre, l'autre le sot, / Li uns bale, li autre note, / Et li autres dist la riote, / Et li tiers dist la genglerie ; / Cil qui vivent de jonglerie / Viellent par devant le conte, / Et teus i ot qui fabliaus conte ; Et li autres dist l'erberie, / Ou il a mainte gaberie : / Et si i a mainte risee." 
bes i pedres precioses que tot ho curen, particularment eficaces per redreçar pius, estretir conys i obrir tots els apetits: "J'ai l'herbe qui les veiz redresce / et cele qui les cons estresce" (vv. 62-63). Recordem que el tractat mèdic català Speculum al foder (s. XIv) recomanava utilitzar, amb la mateixa finalitat, una triaga feta amb saxífraga (planta) mòlta i barrejada amb euforbi (resina), musc (almesc) i oli fi, amb la qual calia untar "la verga e lo pentenill" per "arreçar lo membre" (enravenar-lo) i "moure la voluntat". ${ }^{26}$

Estem davant d'una peça típica del repertori joglaresc que incideix en la paròdia dels "metge-aigüetes" i sanadors escurabutxaques que se la campaven gràcies a la seva fantasia verbal i el seu joc retòric fet d'acumulacions, enumeracions i redundàncies, $\mathrm{i}$ amb els seus contrastats desacords entre la meravella i la trivialitat absurda, font de comicitat incontestable. No de bades el Dit de l'Herberie ha estat considerat el prototipus del monòleg dramàtic que projecta la teatralitat al bell mig de la plaça del mercat i de la població badoc. Tot fa pensar que s'inscriu en les falques de màxima teatralitat que hi ha inserides en el drama litúrgic, d'on prendria peu, i en els misteris ulteriors, que al seu torn el prendrien per model.

\section{L'ESCENARI?}

En la línia de fecundar les hipòtesis amb noves mirades crítiques se situa el conjunt d'estudis que ha reunit Michel Rousse al llibre La scène et les tréteaux (2004) —l'escena i l'enfustat-, d'on destaca la seva anàlisi de l'escenari on els joglars desenvoluparien les seves activitats més teatrals.

Com és sabut durant tota l'època medieval la noció correcta de teatre desapareix, de tal manera que quan els primers humanistes dels segles XIV i XV provaran de reconstruir el model d'aquesta activitat que desconeixen —el teatre- de la qual en troben empremtes en els textos antics, i imaginen tipologies d'aparença prou sorprenent. [Fig. 17] Els autors i erudits medievals quan parlen de teatre imaginen el teatre i l'escena romana, que conceben segons una tradició erudita esquitxada d'errors interpretatius, com creure que les peces no eren representades, ans llegides per un recitador mentre que els actors mimaven l'acció amb gestos apropiats. ${ }^{27}$ Es concep, doncs, el teatre llatí com a recitació d'un text per un lector,

26 Speculum al foder, a cura d'A. Alberni, Bellcarire d'Empordà, 2007, pp. 73-74.

27 Un malentès que es remunta a una mala interpretació d'un passatge de Titus Livi (vII, 2) i de Valeri-Maxim (II, 4), i a l'errònia resolució de l'abreviatura "rec" dels manuscrits de les obres de Terenci comentades per Calliopius, un gramàtic del s. II-IV: el "rec" es llegeix recitavit en lloc de recensuit i hom pren el comentador pel recitador. Apud S. Menegaldo, "Les jongleurs dans le théatre profane en France au XIII ${ }^{\mathrm{e}}$ siècle. Acteurs, musiciens, auteurs", a XII Congres de la S.I.T.M. (Lille 2007), en xarxa <http://sitm2007.vjf.cnrs.fr/pdf/s9-menegaldo..pdf>. 
acompanyat per un joc de mims. Els malentesos comencen a les Etimologies d'Isidor. ${ }^{28}$ [Fig. I8] És significatiu que Huguccio de Pisa a la ratlla de I200 defineix l'escena com un umbracle dintre del teatre, un lloc tancat amb cortines semblant a les parades dels mercaders. ${ }^{29} \mathrm{Al}$ text d'Isidor l'escena es definia com una construcció amb aparença de casa, però enlloc no hi diu res de cortines, que només apareixen a finals del s. XII i es retroben en definicions ulteriors i també en les miniatures que il.lustren els manuscrits amb obres de Terenci i aspiren a donar fe del teatre romà. [Fig. 19] En els seus comentaris a les Tragèdies de Séneca, Nicolas Trévet encara afegeix més confusió i diu que "el teatre era una àrea semicircular al mig de la qual hi havia una petita caseta anomenada 'escena'; al seu interior hi havia una trona on el poeta declamava els seus versos. A l'exterior hi havia els mims que representaven amb llurs gestos i actitud corporal el contingut de la declamació, interpretant el personatge de què parlava el poeta"..$^{30}$ És aquest text qui inspira la miniatura de l'Hercules furens on sobre de la caseta del poeta hi ha els distints personatges de la peça i a sota el cor tràgic, mentre que a l'exterior del semicercle se situen els espectadors. Una tipologia que també es tindrà present en les il.lustracions dels manuscrits terencians [vegeu Fig. 7].

Però, per què s'associa el concepte d'escena a una modesta estructura feta amb quatre pals i uns cortinatges? Sens dubte perquè una cosa semblant existent en la realitat de l'època devia suggerir primer als erudits i després als illuminadors. En la visió del pintor de les miniatures que il.lustren les Tragèdies de Sèneca o les Comèdies de Terenci hauria pogut influir, d'una banda, una pràctica de mostració espectacular documentada almenys en l'àmbit eclesiàstic: el sermó representat. [Fig. 20] En aquesta tipologia s'escenificava a les catedrals de Girona, València o Mallorca, l'Ordo prophetarum a les matines de Nadal, en què el predicador o 'lector' anava cridant els profetes per tal que donessin el seu

28 "XLIII. DE SCENA. [I] Scena autem erat locus infra theatrum in modum domus instructa cum pulpito, qui pulpitus orchestra vocabatur; ubi cantabant comici, tragici, atque saltabant histriones et mimi. Dicta autem scena Graeca appellatione, eo quod in speciem domus erat instructa" (Etymologiae, Lib. XVIII, 42-43).

29 "Et a scenos quod est umbra dicitur hec scena; scene, id est umbra, et scena id est umbraculum, locus obumbrans in theatro et cortinis coopertus, similis tabernis mercenariorum, que sunt asseribus uel cortinis cooperte; et secundum hoc scena potest dici a scenos quod est domus, quia in modum domus constructa est. In illo umbraculo latebant persone larvate" (Huguccio DE PisA, Magnae derivationes, II97-I2OI, apud Rousse. La scène et les tréteaux...).

30 "Et nota quod tragedie et comedie solebant in theatro hoc modo recitari: theatrum erat area semicircularis, in cuius medio erat parva domuncula, que scena dicebantur, in qua erat pulpitum, super quo Poeta carmina pronuntiabat. Extra vero erant mimi, qui carminum pronunciationem gestu corporis efficiebant per adaptionem ad quemlibet, ex cuius persona poeta loquebatur”, apud S. Pietrini, "Medieval Entertainers and the Memory of Ancient Theatre", Revue Internationale de Philosophie, 2 (2010), pp. I49-176 (p. I64n de referència). 
testimoni sobre la vinguda del Messies, reforçant així les paraules del predicador. ${ }^{31}$ En una mostració semblant cal situar l'origen de les danses macabres, com explica Du Cange, ${ }^{32}$ que presenten característiques d'un sermó franciscà didàctic i edificant, l'oratòria del qual s'illlustraria i reforçaria amb la dansa i escenes dramàtiques altament expressives: en efecte, la iconografia gòtica de la dansa de la Mort sol encapçalar el ball amb la imatge d'un predicador enfilat al púlpit, que parlaria sobre les vanitats del món i la necessitat de preparar-se en vida per al moment final i convocaria la comparsa macabra. A la Catedral de Mallorca, el I444, va ser Bartomeu Catany, frare franciscà, el responsable de la "representació del Divendres Sant" que es desenvolupava mentre ell predicava des de la trona, per a la qual es construí un "bastiment" o cadafal amb "cinquanta taules" i "dotze botes" on s'instal-lava una "creu maior", presumiblement davant l'altar major, on actuaven els personatges de l'àngel i de Jesús, que utilitzaven, com a utilleria, una altra creu "que aportà l'àngel al Jesús" en la que es pinten "los Improperis", "aigua cuita" i "carmini per fer sanch", ${ }^{33}$ elements sovint utilitzats en escena per als trucs i efectes especials, en aquest cas segurament per evidenciar la sang suada en l'oració a l'hort. L'escena mimada, per tant, podia representar el Verger de Getsemaní, on Jesús pregà, rebé la visita angèlica i fou pres. També el divendres sant de 1460 el predicador Pere Joan Llobet dirigeix des de la trona l'acció dramàtica desenvolupada en més d'un cadafal, amb un decorat d'infern en forma de boca tancada per una tela negra i fet amb cèrcols, sens dubte per representar l'Anàstasi o rescat de les ànimes pel Crist triomfant, amb actors proveïts de màscares i diademes que cantaven en certs passatges, $i$ en què també es representà "lo Llavament de la Creu". ${ }^{34}$ De la mateixa manera, l'illlustrador del manuscrit del Troilus and Criseyde de Chaucer, representa el narrador instal.lat en una domuncula a guisa de púlpit que recita el conte davant el rei Ricard II i altres personatges de la cort anglesa.

[Fig. 2I] D’altra banda tindríem la pràctica escènica joglaresca que, com ha demostrat Michel Rousse, ja d'ençà el segle XII utilitzaria un espai sumari i facilment transportable que es plantaria en qualsevol plaça o esplanada o indret campestre, fet amb quatre fustes i unes teles, semblant a l'escena de les miniatures terencianes. Una estructura de l'espai de representació anàloga a la que es

3I J. Romeu, Teatre català antic, vol. III, p. I9n.

32 Du Cange [Carolo Du Fresne] (I883-1887), Glossarium Mediae et Infimae Latinitatis..., x vols. Niort, I885, v, p. I6I, col. I.

33 G. Llompart, "La catedral gótica de Mallorca como centro difusor de teatro popular", Revista de Tradiciones Populares, XLIII (I988), pp. 359-364.

34 G. Llompart, "Fonts menors i mínimes del teatre medieval mallorquí", dins A. Rossich, A. Serrà i P. Valsalobre, eds., El teatre català dels orígens al segle XVIII, Kassel, 200I, pp. I4I-I5O (pp. I49-I50 de ref.). 
documenta a partir del segle XVI en la iconografia que reflecteix la representació de farces o de peces de la commedia dell'arte.

[Fig. 22] Fixem-nos en la forma d'escenari que recull Pierre Balten (I528-I598) al quadre Kermesse camperola (Museu del Teatre, Rijskmuseum Amsterdam). Observem que l'aspecte que documenta no desdiu de la disposició amb què dos juristes del segle XIII descriuen l'escenari de titelles : Accursius diu que "l'escena és un lloc d'ombra fet amb cortines, emplaçada en un lloc públic o privat, i s'anomena escena per "scenen" que significa una corda, perquè els joglars accionen cavalls amb una corda i altres coses semblants". ${ }^{35}$ També Odofredus pren per exemple les marionetes que es representen arran d'una festa: "Llavors arriben els joglars i instal.len les seves tendes o cortines en algun lloc; tenen cavalls de fusta i s'estan a l'interior dels cortinatges, i accionen els seus cavalls amb cordes" ${ }^{36}$

[Fig. 23] A banda del curiós joc de titelles de taula que il.lustrava un manuscrit perdut de l'Hortus deliciarum d'Herrade de Landsberg: ${ }^{37}$ [Fig. 24] una insòlita tipologia que hem retrobat al segle XviII en una pintura de Granieri (Il Pifferaio I750, Palazzo Madama, Torino), tenim diverses mostres de teatrins de titelles medievals [Fig. 25] com els que apareixen als marges del magnífic manuscrit d'Oxford de $L i$ romans d'Alexandre, perquè com acabem de dir les titelles eren plat comú entre els espectacles joglarescos realitzats en les festes cortesanes com la que descriu el Roman de Flamenca al s. XIII ("L'us fai lo juec dels bavastelz", v. 6II) $3^{8}$ En l'una no hi ha cavalls però sí garrotades: aquí s'insinua una baralla de capçal entre una parella on l'home duu un garrot plausiblement per usar-lo, i en l'altra [Fig. 26] les maces les

35 "Scena est obumbratio cortinarum quae posita sunt in publico vel in privato loco, et dicitur scena a scenen, quod est corda, quia joculatores faciunt ire caballos per choardam et similia" (Accursius, inici s. XIII).

36 "Nam veniunt joculatores et poniunt cortinas in aliquo loco et habent equos ligneos et stant intus cortinas et faciunt ire caballos per cordas" (Odofredo, mitjans s. XIII). Apud Rousse, La scène et les tréteaux...

37 "Ludus Monstruorum: In ludo monstr[u]orum designatur vanitas vanitatis", HerRade DE LANDSberg, abadessa de Hohenburg, Hortus deliciarum (manuscrit destruït, fol. 2I5, copiat el I8I8 per Christian Moritz).

38 Altres testimonis al v. 317I del roman d'aventures Guillaume de la Barre (I3I8) d'Arnaut Vidal de Castèlnòu d'Arri (ed. P. Meyer, París, I895). En francès antic, 'baasteaus', 'basteaus', d'on deriva 'basteleur de marionettes' (puppet-player). En català, el mot apareix en R. Llull: "axí com lo bavastell qui demostra semblansa d'ome e és de fust e pintura" (Llibre de contemplació, I3, cap. 239), i en Jacme Roig: "molts plasents jochs, / bastir castells / per bavastells, / moms e grans festes" (Spill, I486). A la cort de Pere el Cerimoniós es paguen 50 sous barcelonesos a "Hiixeni, moro, juglar de bavestells, los quals graciosament li manà donar" (II-V-I346, document ACA, Reial Patrimoni, MR, reg. 868, fol. 26r. que em facilita Stefano M. Cingolani, que l'ha transcrit per al projecte de l'European Research Council "The Last Song of the Troubadours. Linguistic Codification and Construction of a Literary Canon in the Crown of Aragon" (FP7 2009-2013-240170), amb seu a la Universitat de Barcelona, coordinat per Anna Alberni). 
duen dos soldats que emmarquen el combat de dos personatges amb espases (suposem que hi ha un sol titellaire que manipula els dos ninots en acció, però els altres dos els podia agafar en qualsevol moment). Una estructura que ha perviscut fins als nostres dies tant a Orient com a Occident, on l'escenari rep el nom de "castellet", pel seu aspecte, és clar. I amb el nom "castell" ja es menciona al citat sirventes-ensenhament de Girauz de Calanson dirigit al joglar Fadet (principis s. XIII): "E paucs pomelz / ab dos coltelz / sapchas gitar e retenir; / e chants d'auzelz / e bavastelz, / e fai lor castels assaillir”. Nom que passaria a designar al segle XIV o començos del XV els cadafals escènics de les representacions urbanes, [Fig. 27] que no serien gaire diferents als que dibuixa Brueghel en certs gravats on sol haver algú entre telons $\mathrm{amb}$ un text possiblement per apuntar els inèrprets. [Fig. 28] Un enfustat muntat sobre barrils i la caseta tancada amb cortines des d'on surten els actors, [Fig. 29] que retrobem en altres mostres pictòriques dels segles XVI i XVII, amb expressives semblances a les parades de mercat amb què comparava Huguccio de Pisa l'escena teatral (I200). [Fig. 30] És la mateixa disposició escènica que utilitzen els comediants de l'art, hereus directes de la joglaria medieval. També els arguments de la commedia dell'arte es començarien a perfilar en les escenes amb què aquests joglars transvestits enriolarien el seu públic.

I potser també era la tipologia adoptada per l'Ordo Representationis Adae (c. II5O) que per figurar el paradís terrenal rubrica:

Constituatur paradisus loco eminenciori; circumponantur cortine et panni serici, ea altitudine, ut persone, que in paradiso fuerint, possint videri sursum ad humeris; servantur odoriferi flores et frondes; sint in eo diverse arbores et fructus in eis dependentes, ut amenissimus locus videratur. ${ }^{39}$

És a dir, que presentaria una fesomia d'entaulat (elevat) amb un espai (al fons) tancat per cortines que no arribarien al metre i mig d'alçada per tal de permetre veure, de muscles en amunt, els intèrprets que eren al seu interior, tot i que també servís per permetre canvis de vestuari, etc. Nova constatació de la incidència de la pràctica escènica joglaresca en representacions de caire religiós fins i tot a l'interior del temple (com sembla ser el cas de l'Ordo).

[Fig. 3I] Disposicions semblants d'espais tancats amb cortinatges (aquest cop, però, per descobrir-se en començar l'acció i permetre contemplar el seu interior) serien els tableaux vivants utilitzats en els grans seguicis cívics, com en l'entrada de Joana d'Aragó a Brussel.les el I497.40 I això ja ens condueix de ple a la configuració de l'escenari modern.

39 S. M. Barillari (ed.), Adamo ed Eva. Le Jeu d'Adam: alle origini del teatro sacro, Roma, 20Io, p. I46. 40 F. Massip, A cos de rei. Festa cívica i espectacle del poder reial a la Corona d'Aragó, Valls, 20Io, pp. I75-I94. 


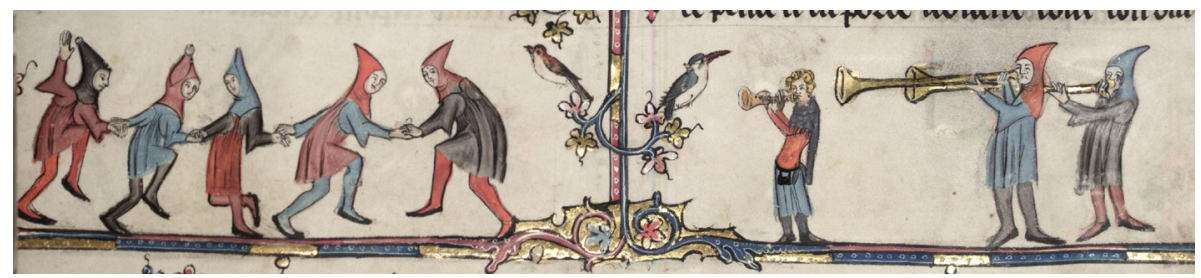

I. Joglars en dansa i trompeters. Roman d'Alexandre, Oxford Bodleian Ms 264, fol. 78r.

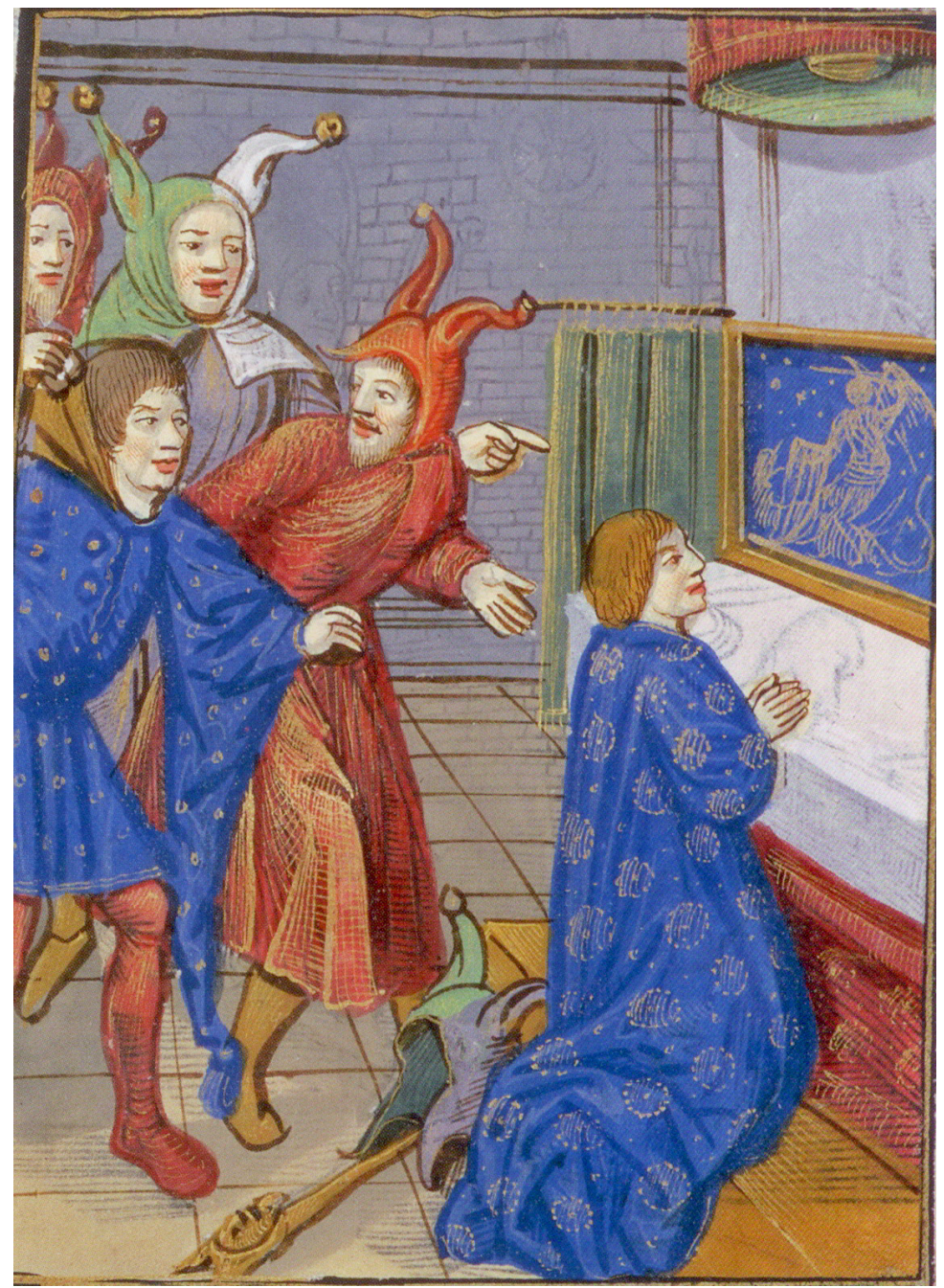

2. Joglar pietós. Sebastian Brandt, Nef des Folz du Monde (I497), BNF Res Livres Rares Vélins 607 fol. II9v. 


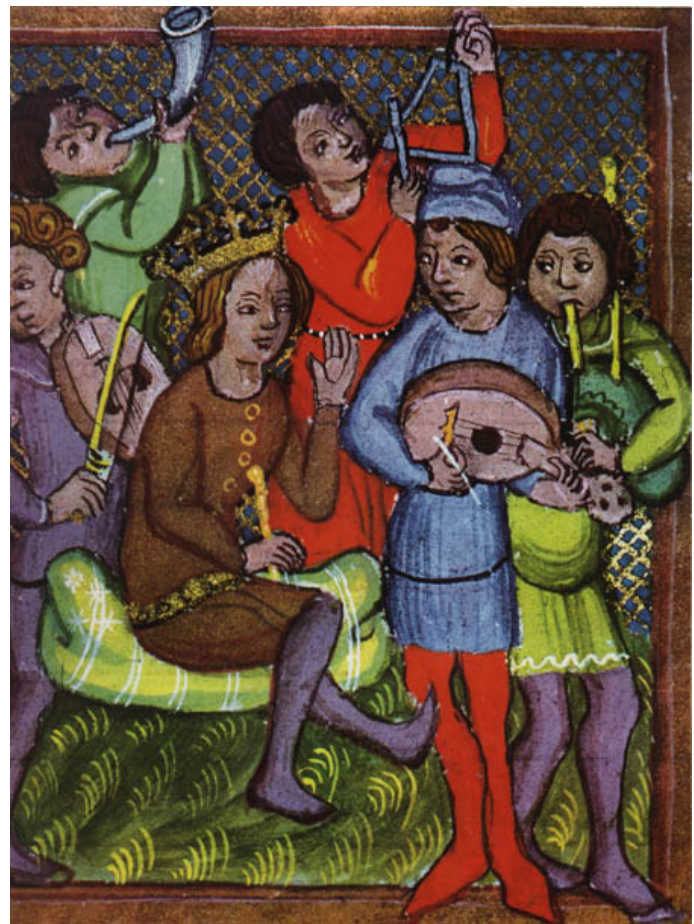

3. Rei David envoltat de Joglars, Bíblia d'Olomouc (República Txeca), Biblioteca Universitària Ms III.I, Psalm 8I (I4I7).

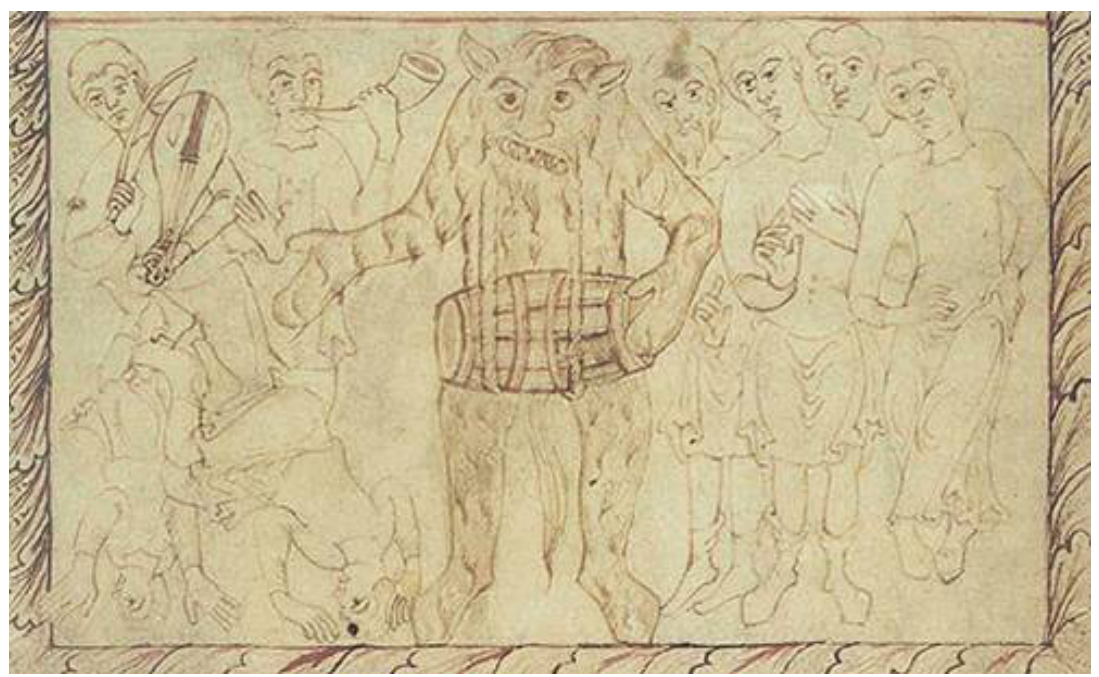

4. Saltiri de Cambridge, St. John College, B I8 (c. II40), fol. I. 


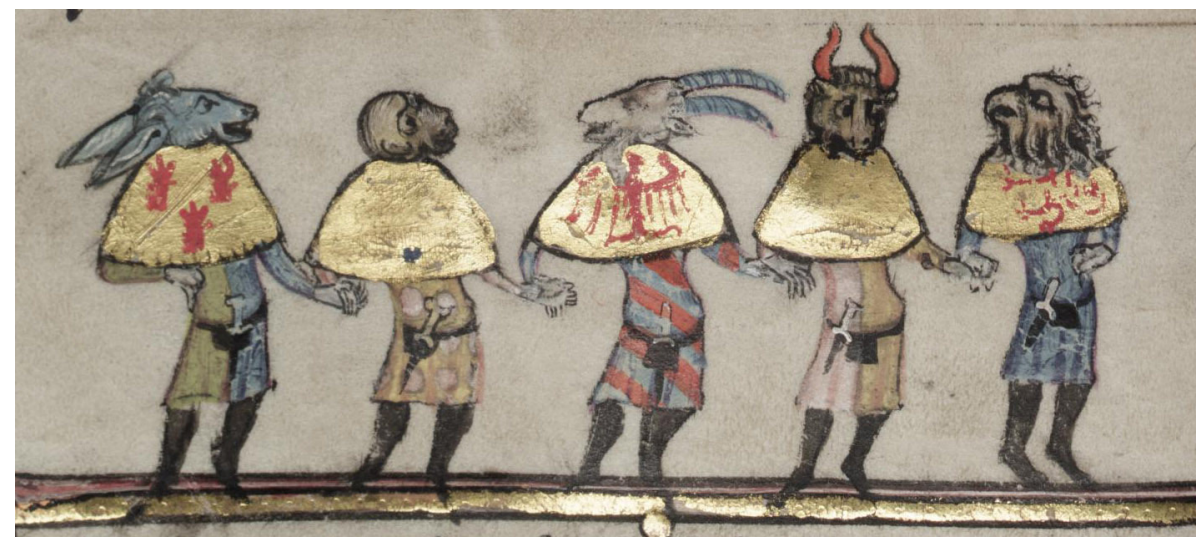

5. Dansa animalia. Roman d'Alexandre, Oxford Bodleian Ms 264, fol. I8Iv.

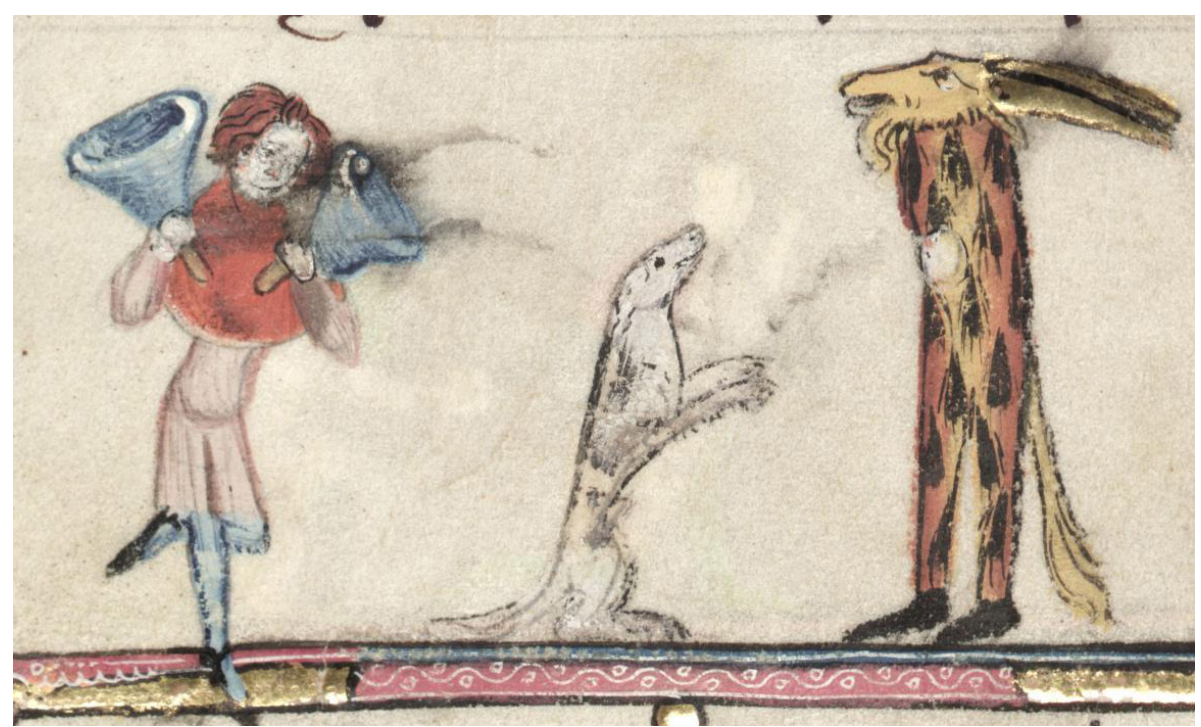

6. Màscara de cabra. Roman d'Alexandre, Oxford Bodleian Ms 264, fol. II7v. 


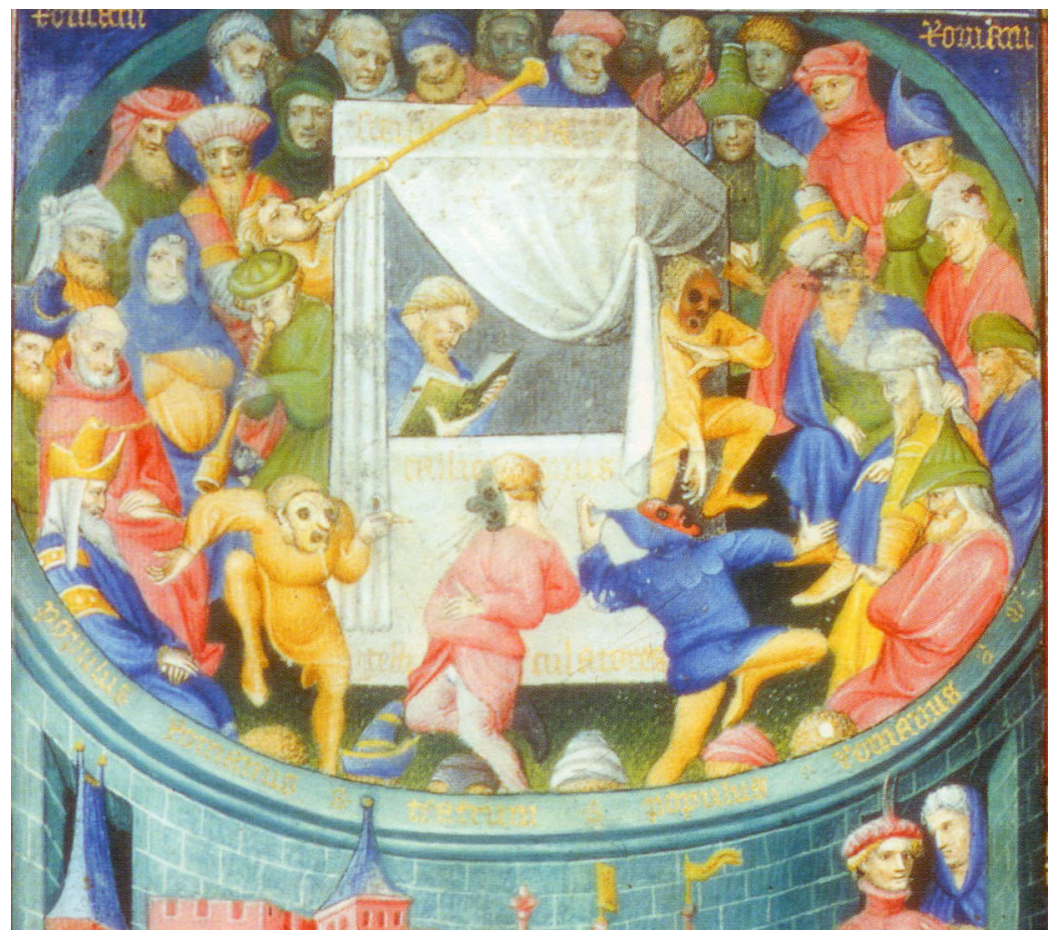

7. Terenci del Duc de Berry, frontispici, BNF, Ms Lat. 7907a (s. XIV) (olim Bigotianus).

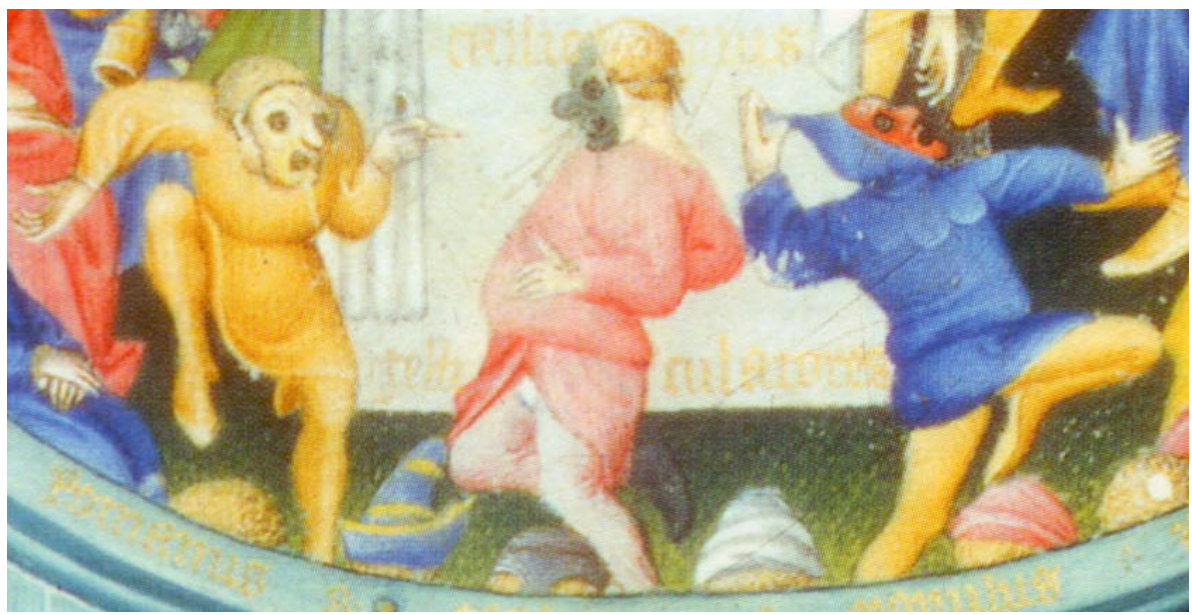

8. Detall d'actors amb màscara. Terenci del Duc de Berry, frontispici, BNF, Ms Lat. 7907a. 


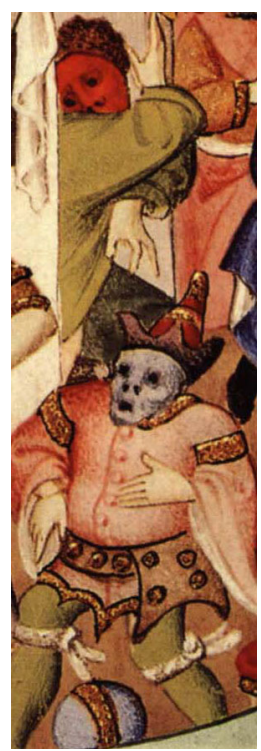

8. Detall d'intèrpret emmascarat. Térence des ducs, Biblioteca de L’Arsenal (París), Ms 664, fol. Iv.

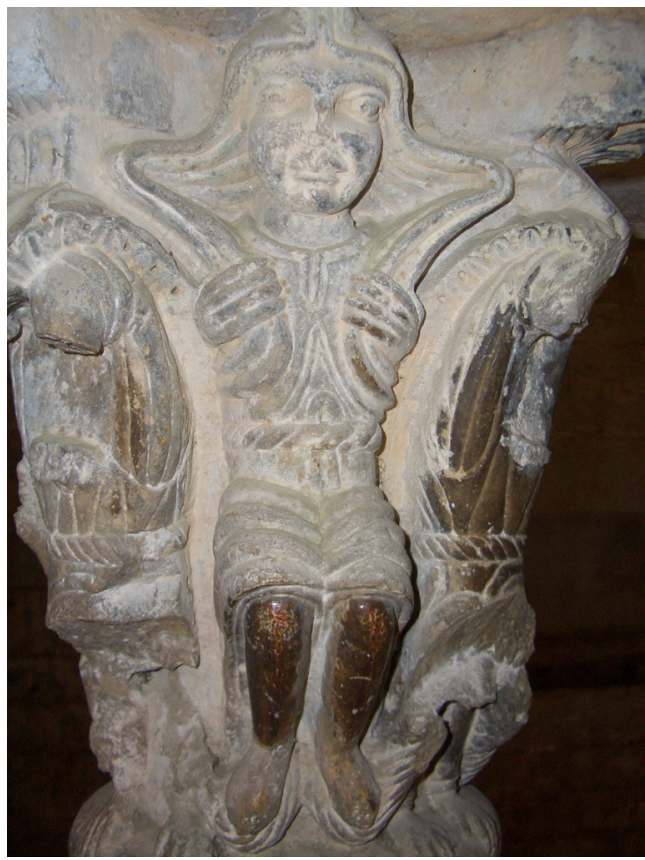

9. Joglar transvestit. Capitell del claustre de St Pere de Galligans, Girona. 


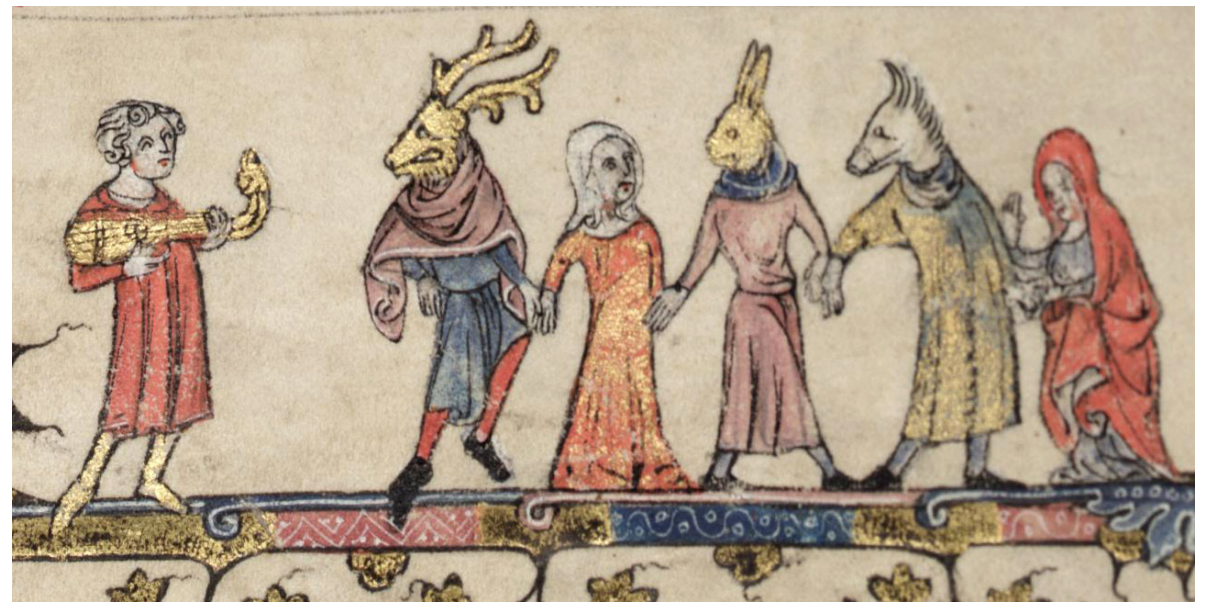

Io. Dansa amb màscares d'animals. Roman d'Alexandre, Oxford Bodleian Ms 264 fol. 2Iv.

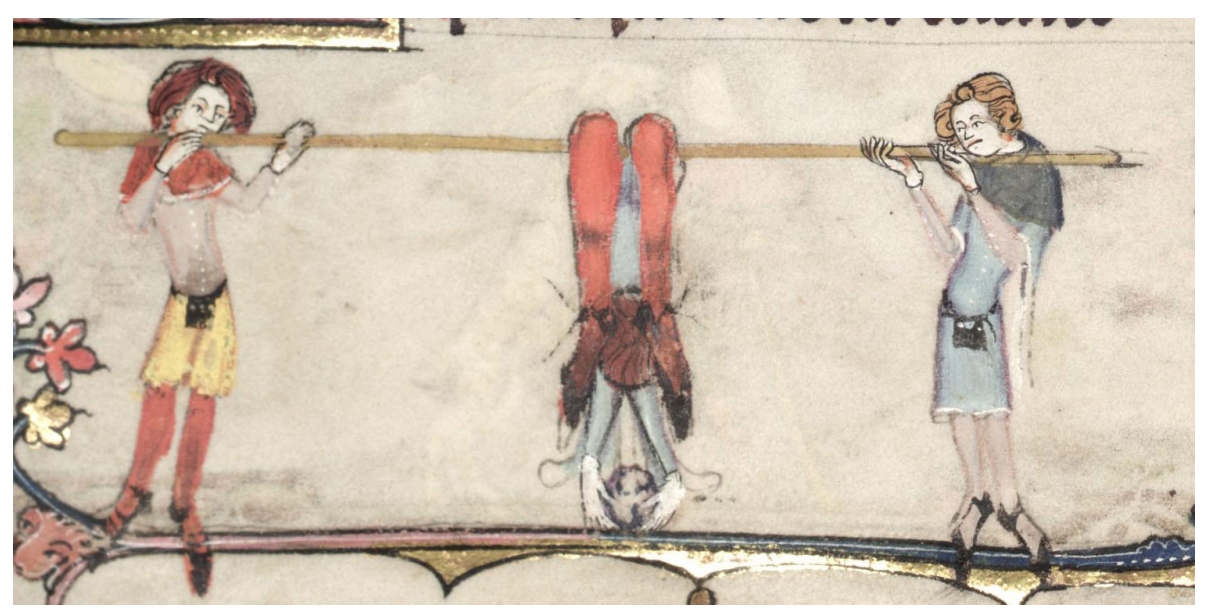

II. Contorsionista. Roman d'Alexandre, Oxford Bodleian Ms 264 fol. Io8v. 


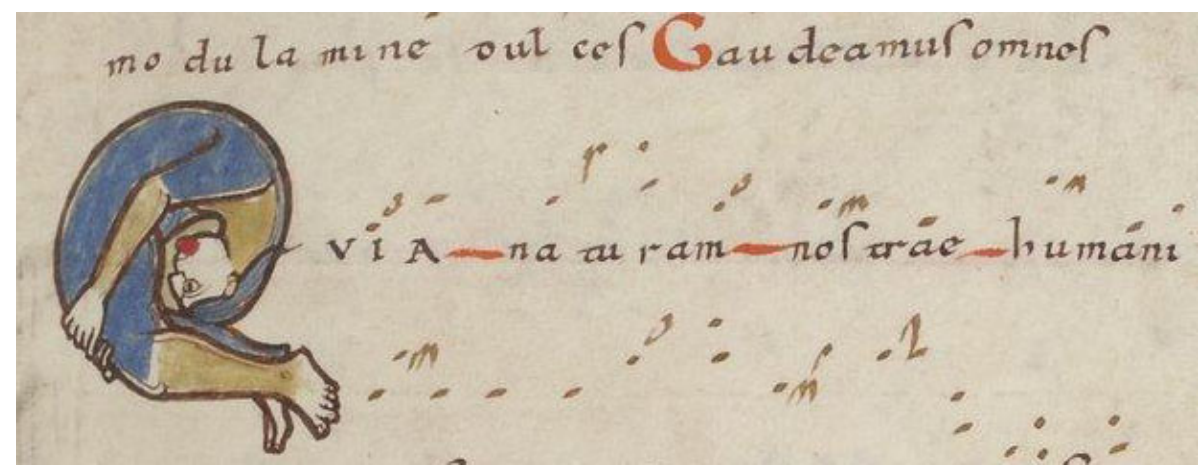

I2. Acròbata en forma de 'Q': “Gaudeamus omnes Qui a naturam nostrae humanitatis copulavit naturae suae divinitatis", trop que ve a dir: "Alegrem-nos tots que a la nostra natura humana s'hi uneix la seva natura divina [de Crist]", Tropari St Marçau de Lemòtges, BNF Ms Lat III’ fol. 69.

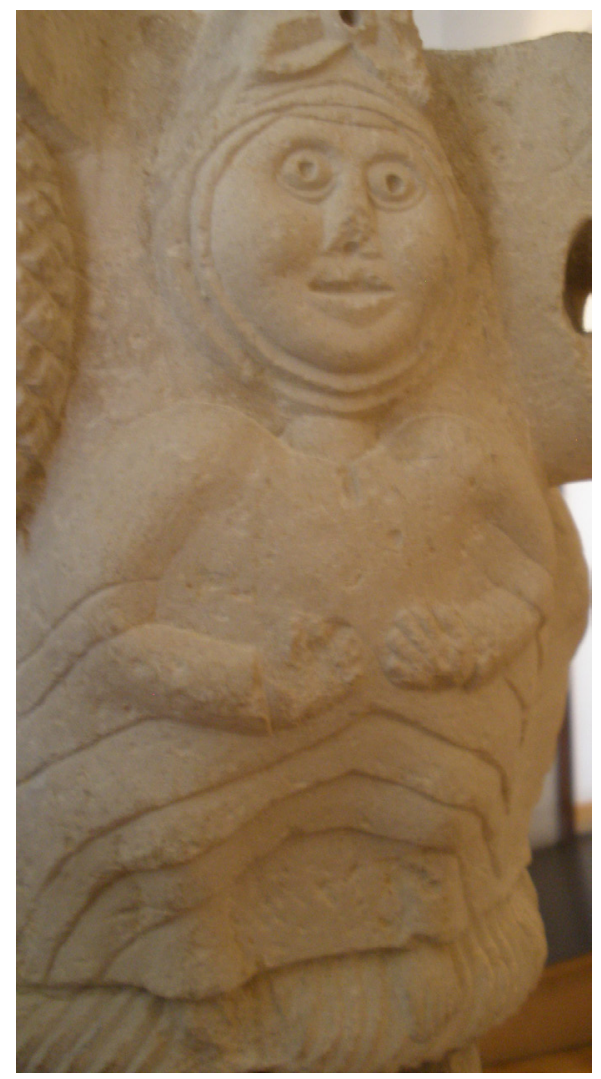

I3 a. Capitell dels monjos eloqüents. Museu d'Art de Girona. 


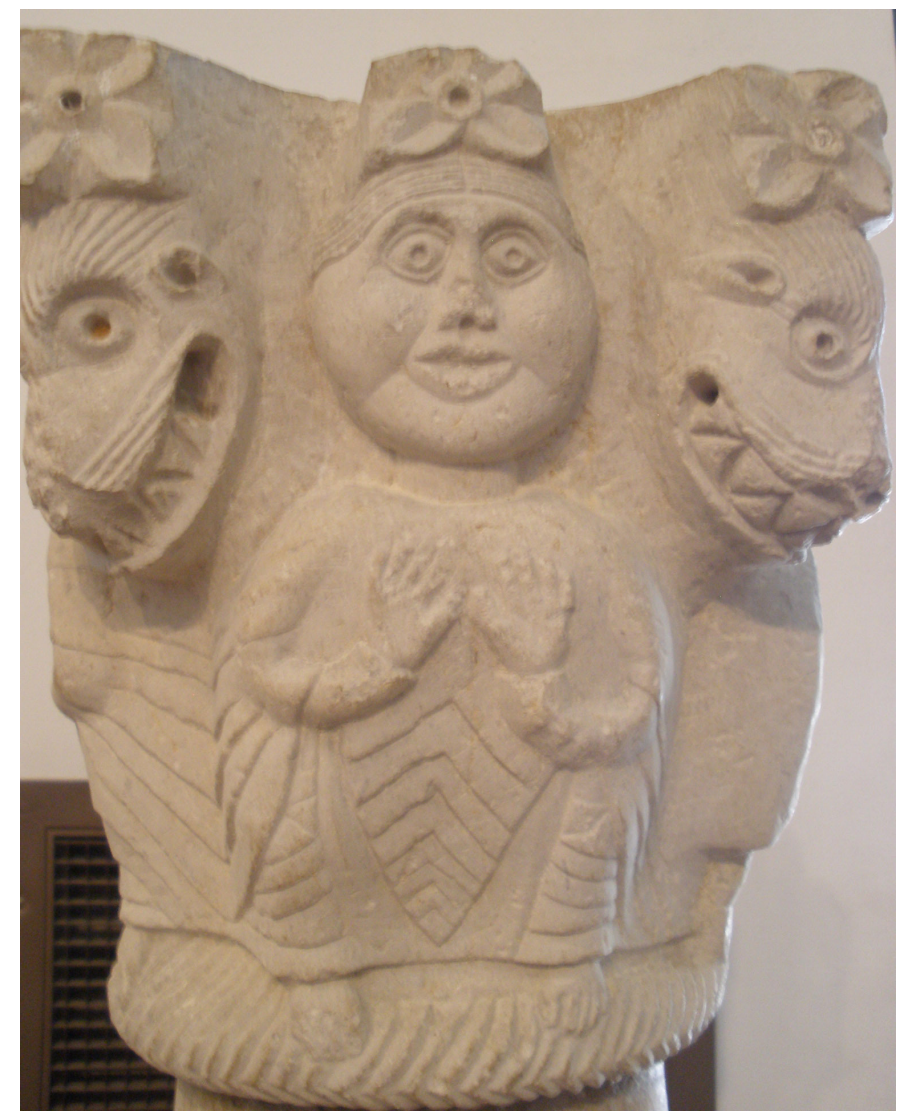

I3 b. Capitell dels monjos eloqüents. Museu d'Art de Girona.

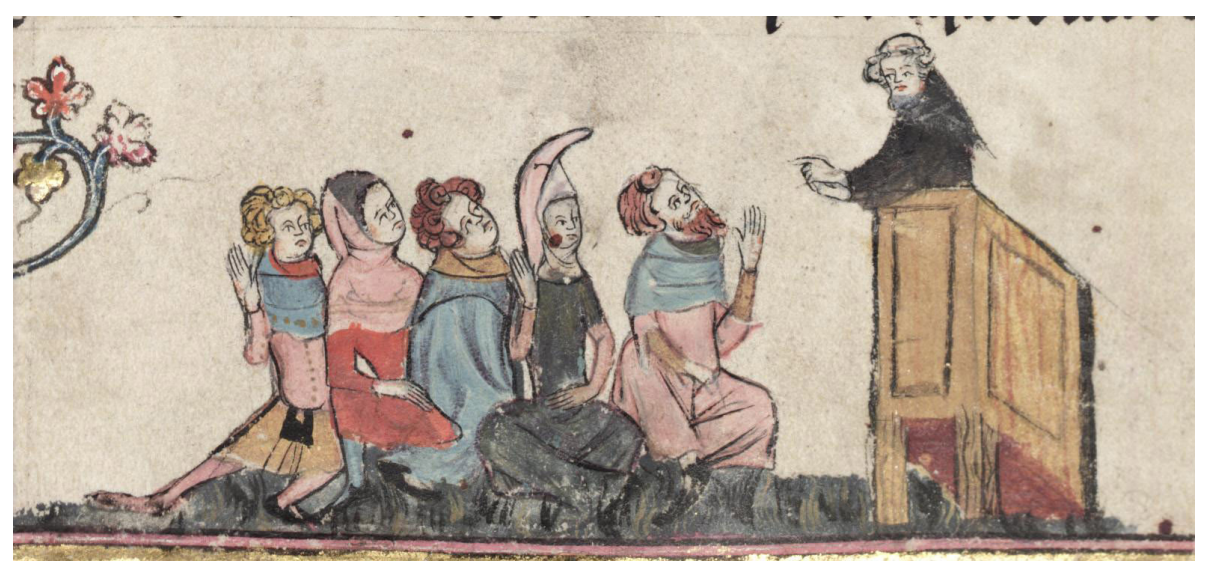

I4. Predicació. Roman d'Alexandre, Oxford Bodleian Ms 264, fol. 79r. 


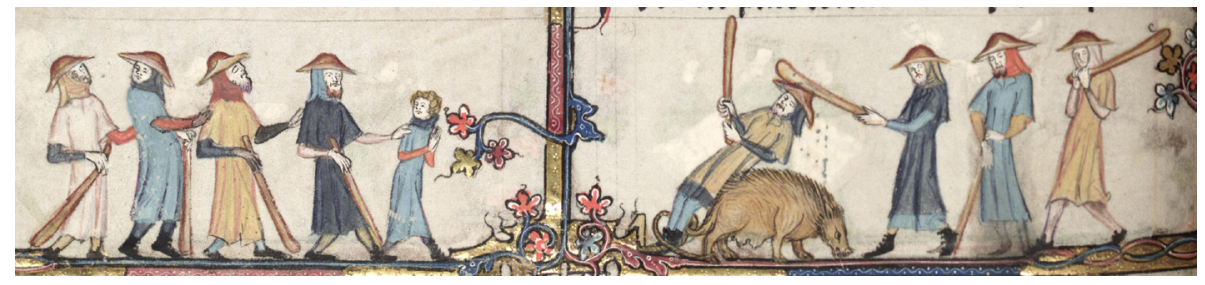

I5. Garrotades de farsa. Roman d'Alexandre, Oxford Bodleian Ms 264, fol. 74v.

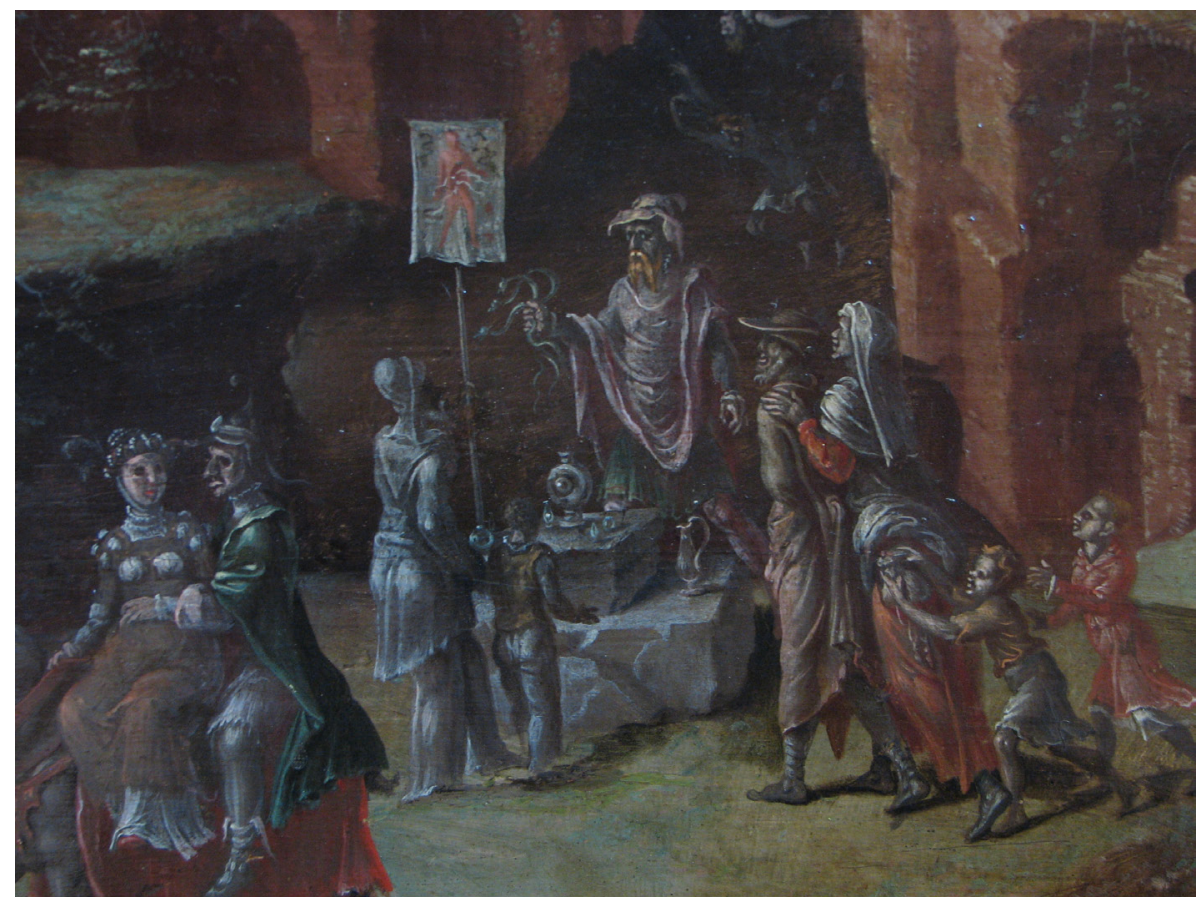

I6. Detall de Mercader. Maerten Jacobsz Van Heemskerk, Braus al Coloseo de Roma (I552), Musée de Beaux Arts de Lille. 


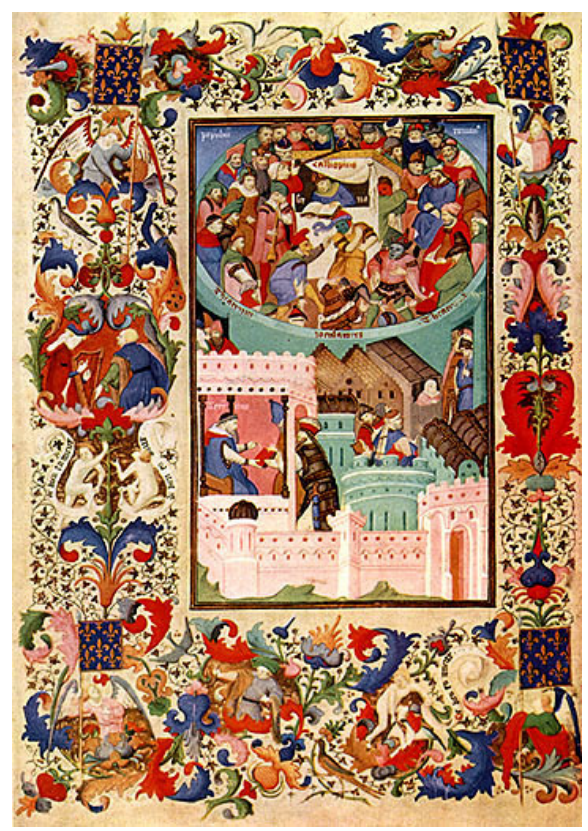

I7. Térence des ducs, frontispici, Biblioteca de L'Arsenal (París), Ms 664.

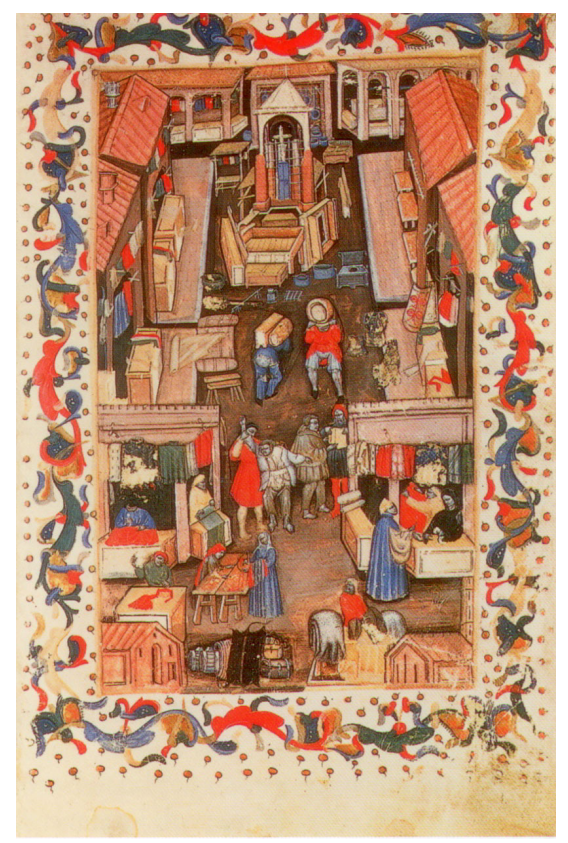

I8. Mercat de Porta Ravegnana de Bologna el I4II. 


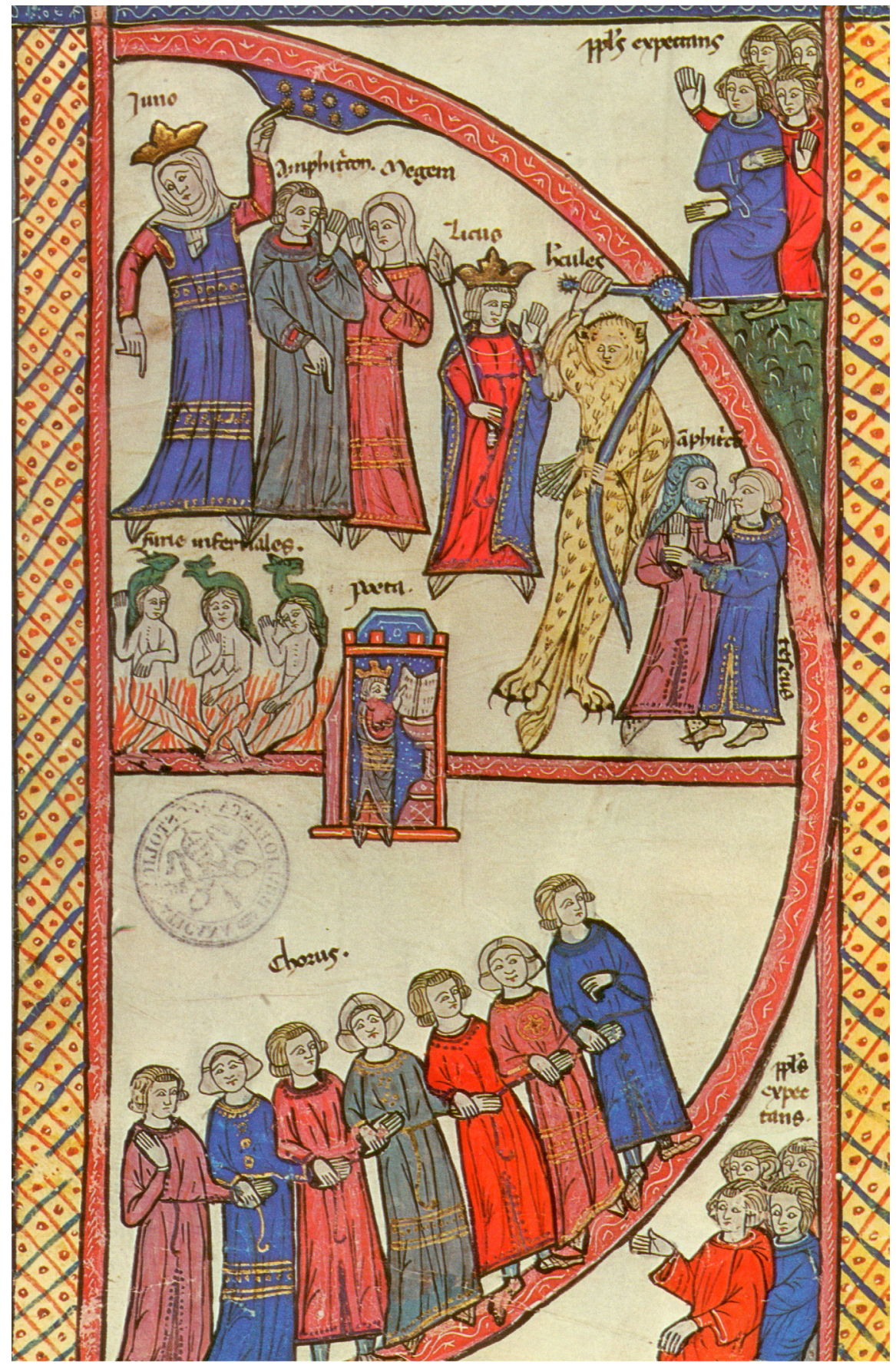

I9. Hercules furens de Séneca, Biblioteca Vaticana, Còdex Urbinate 355. 


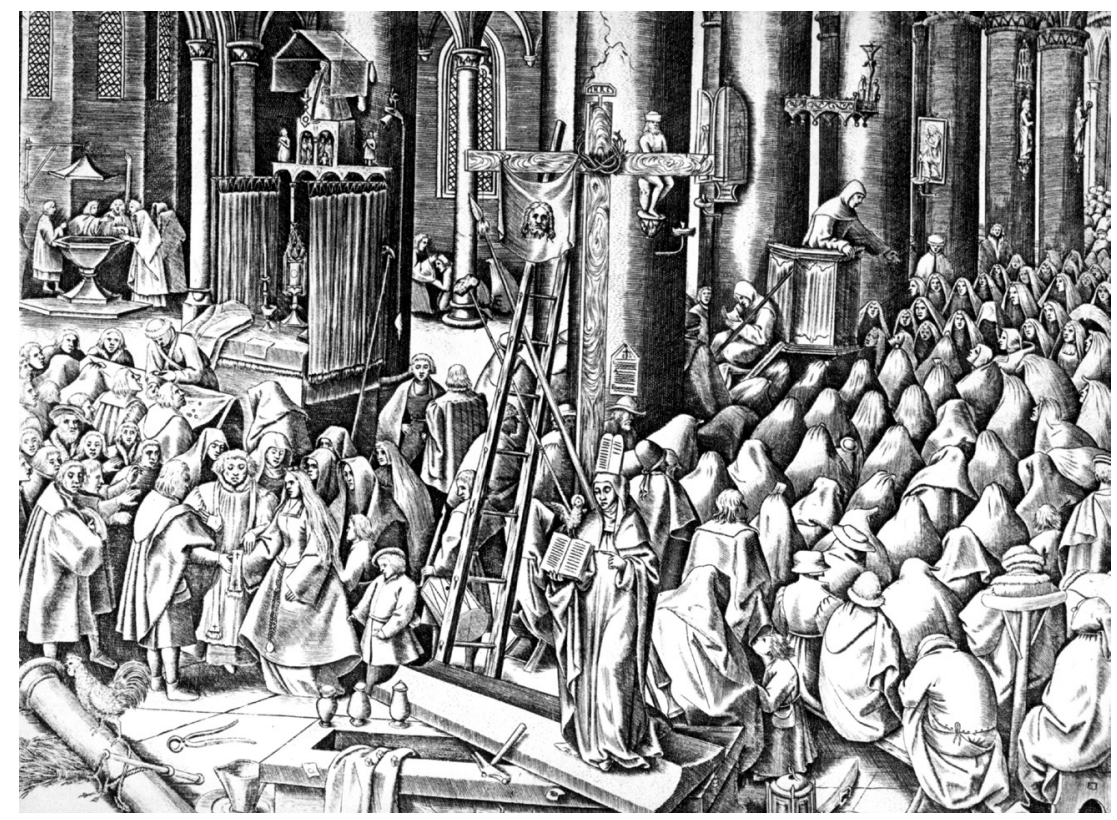

20. Sermó dramatitzat (improperis de la Passió, Sepuclre buit, Davallament). Gravat de Brueghel de les 7 Virtuts (la Fe) (I559-6I).

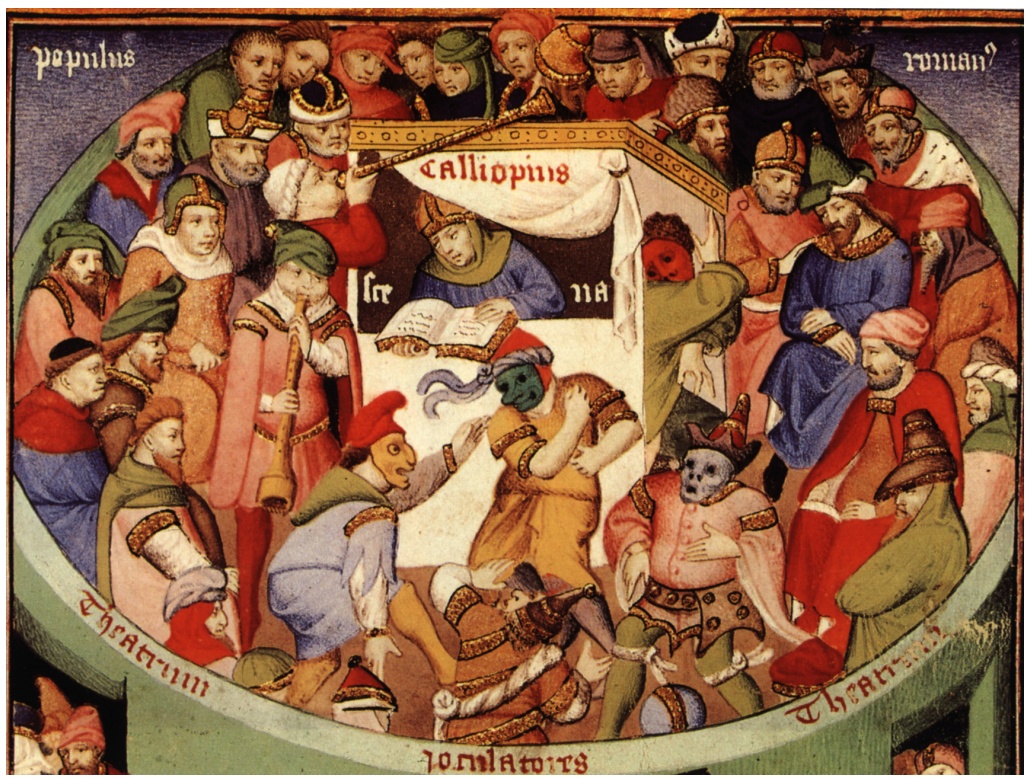

2I. Detall central del frontispici del Térence des Ducs, Biblioteca de L'Arsenal (París), Ms 664. 


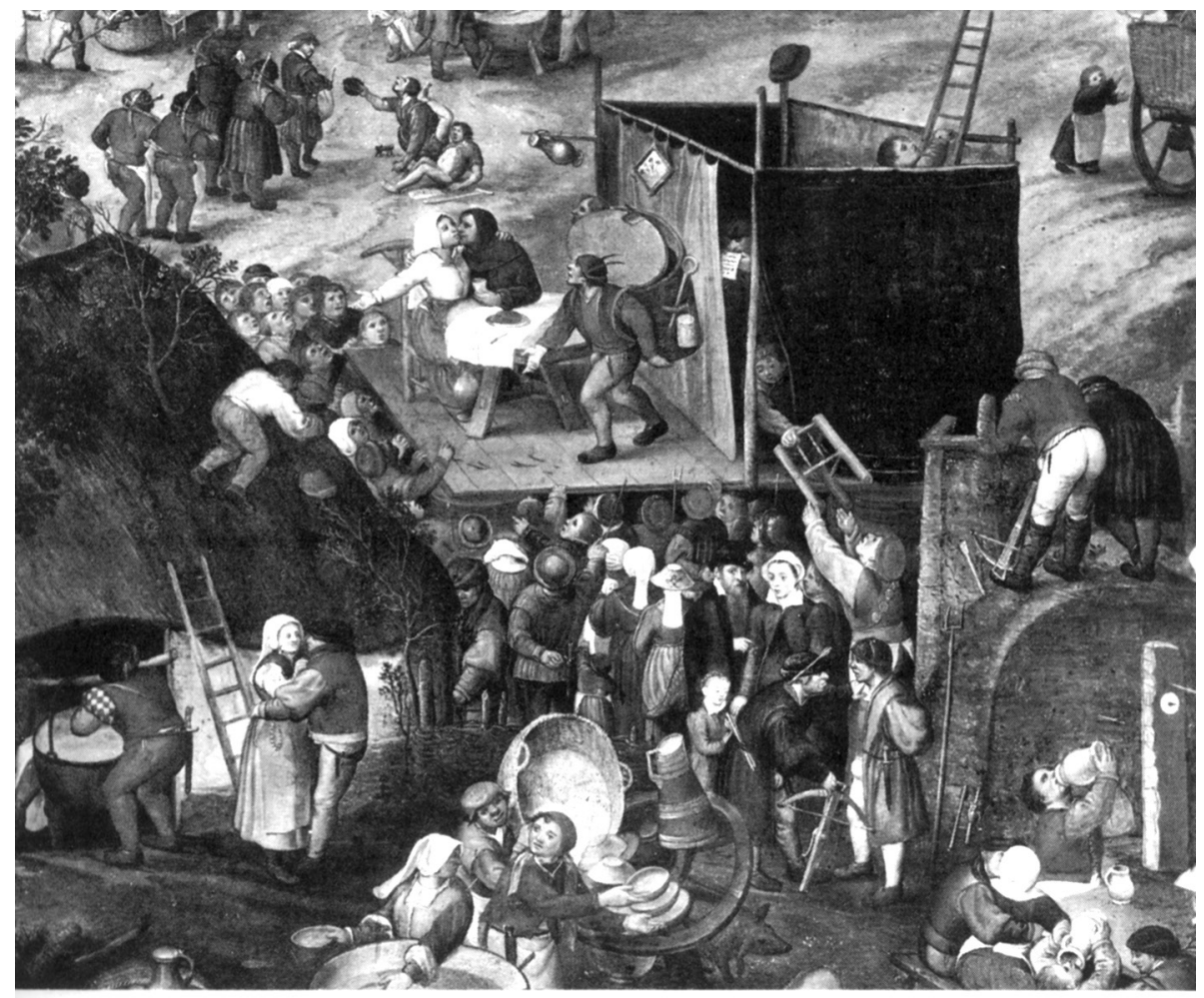

22. Escenari de farsa. Pieter Balten (I528-1598), La Kermesse o Fira Pagesa (detall), Museu del Teatre, Rijskmuseum Amsterdam.

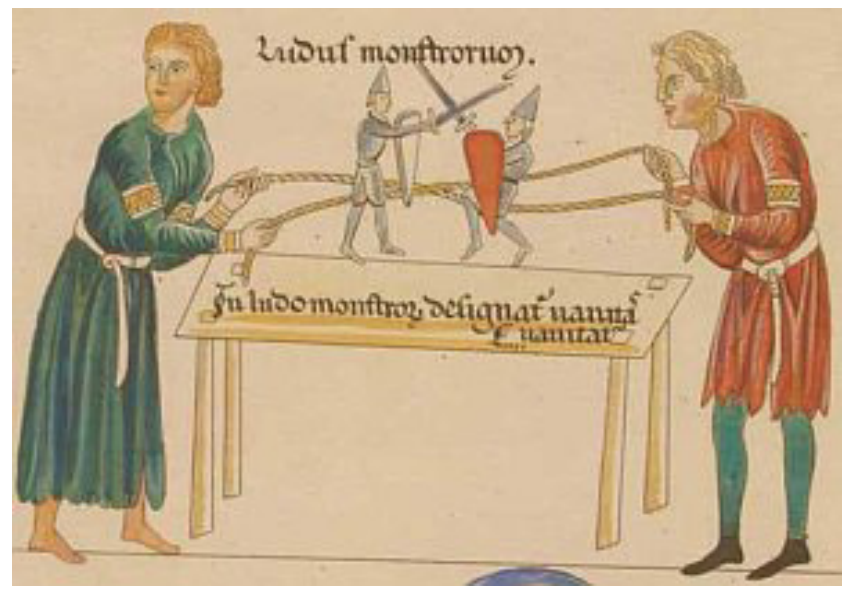

23. Herrade de Landsberg abadessa de Hohenburg, Hortus deliciarum (manuscrit destruït, fol. 2I5, copiat el I8I8 per Christian Moritz) 


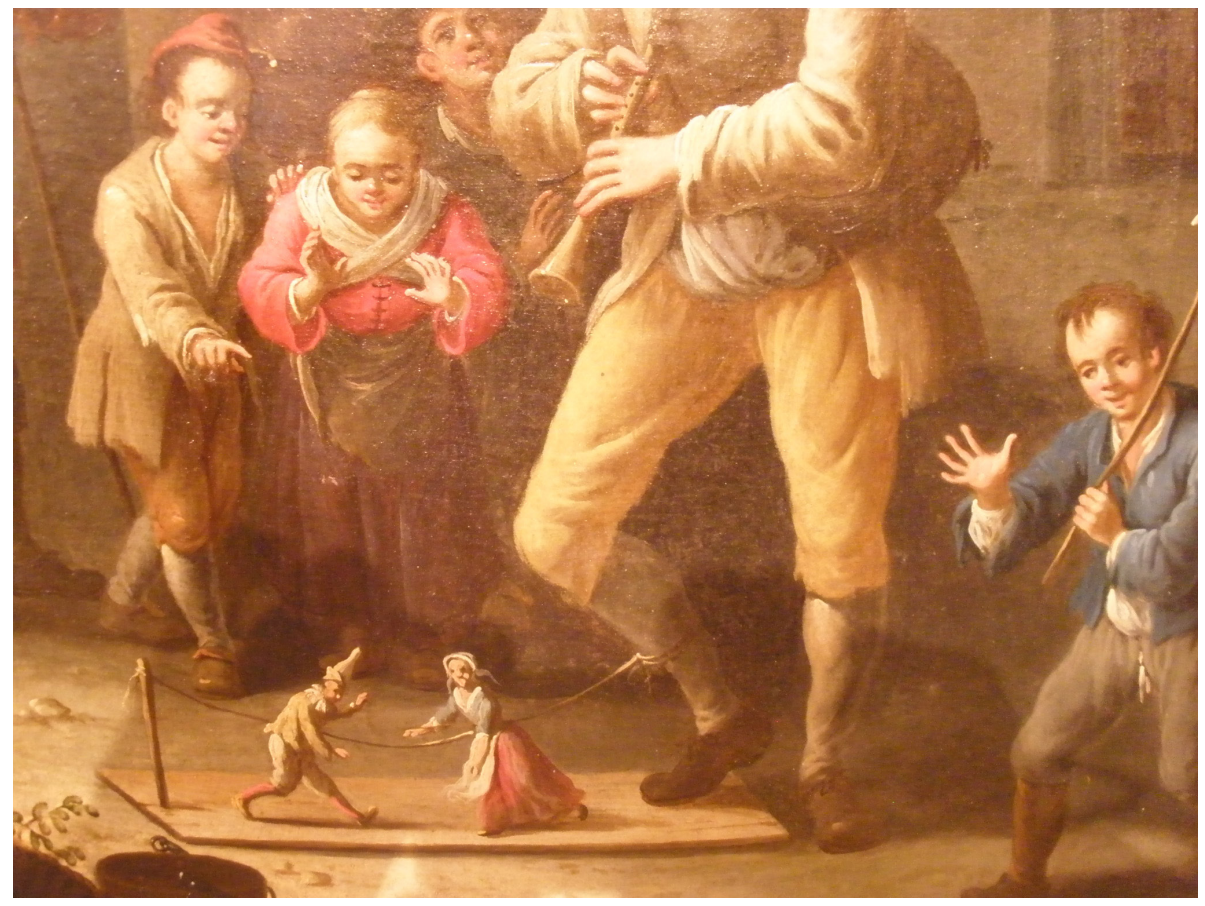

24. Detall de Granieri Il Pifferaio (I750), Palazzo Madama, Torino.

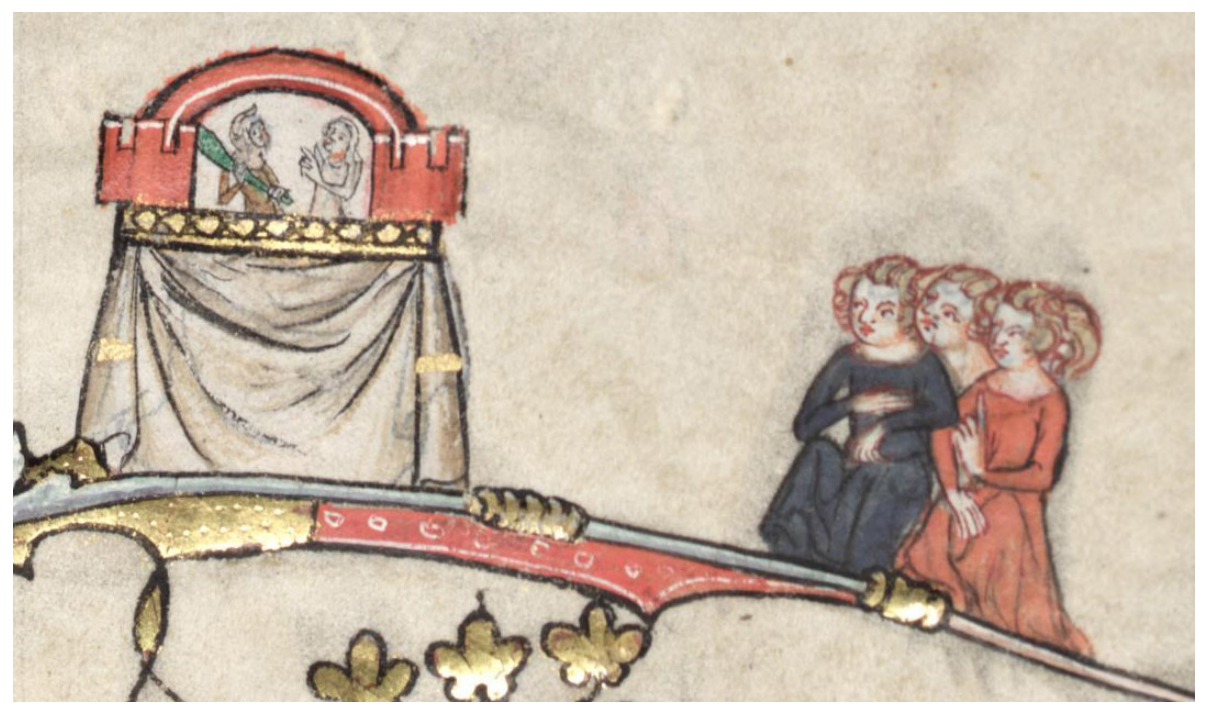

25. Titelles. Roman d'Alexandre, Oxford Bodleian Ms 264, fol. 54v. 


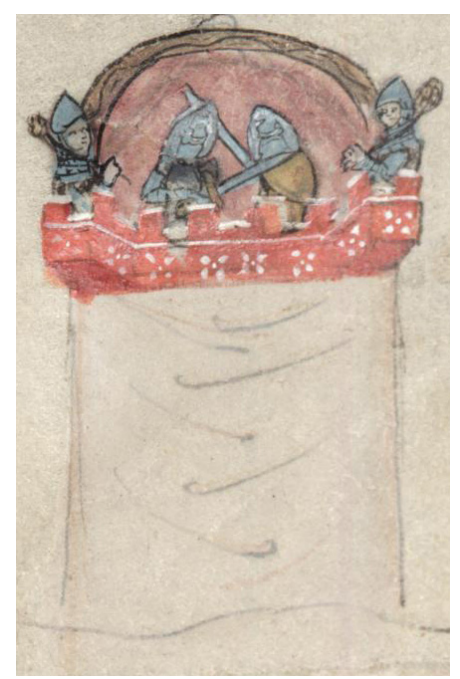

26. Castellet de titelles. Roman d'Alexandre, Oxford Bodleian Ms 264, fol. 76r.

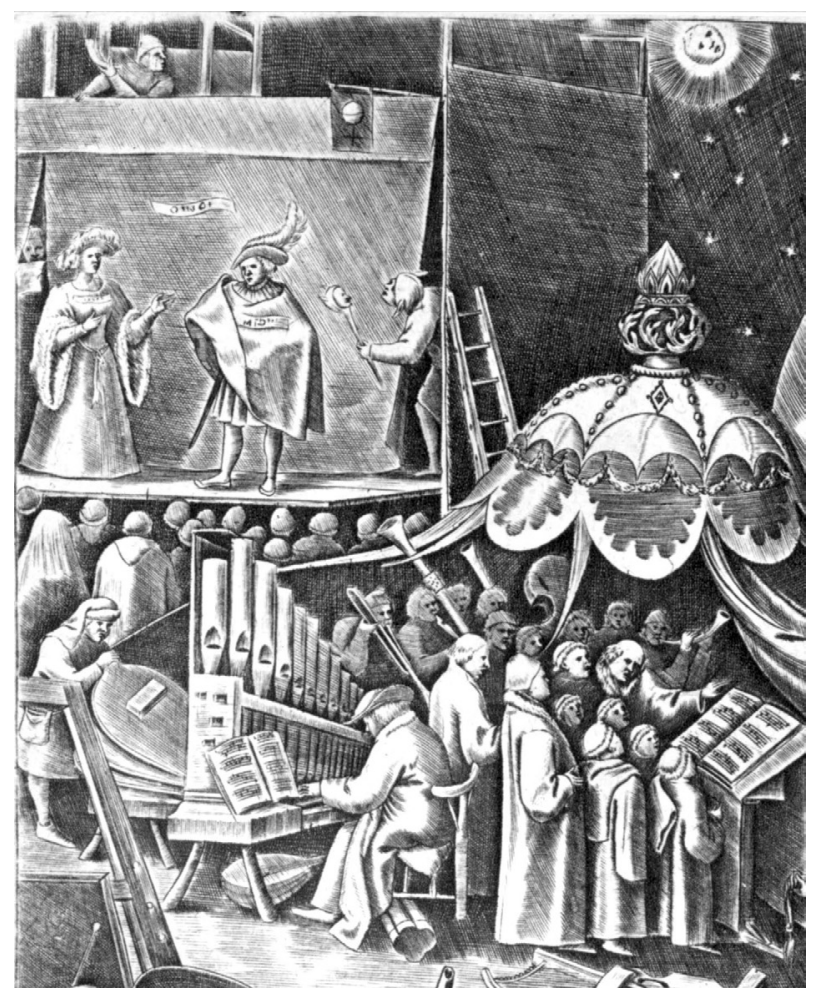

27. Brueghel el Vell, detall del gravat Temperança de la serie Les Set Virtuts (I559-6I). 


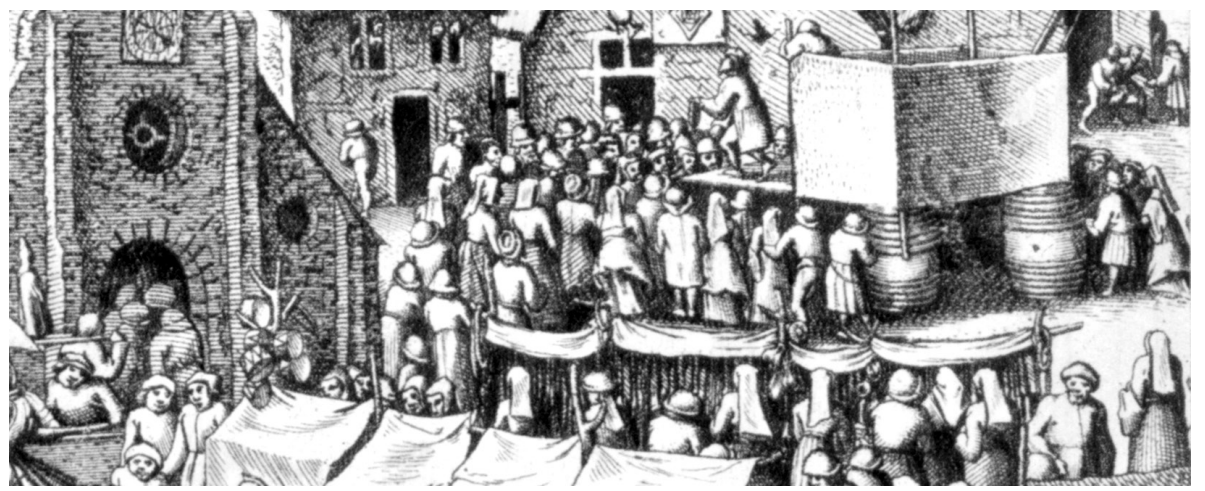

28. Brueghel, detall d'escenari on es representa una farsa en la Festa de S. Jordi.

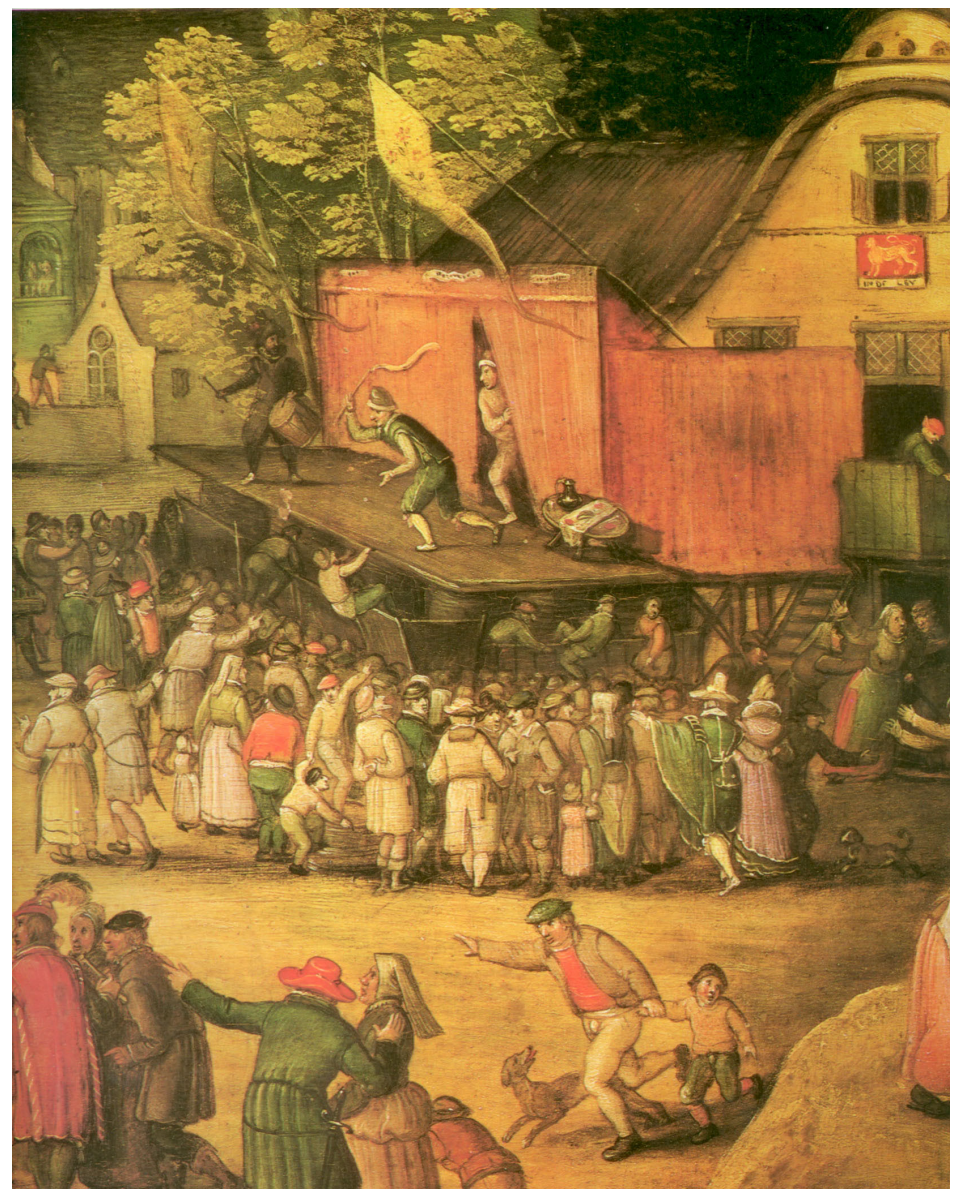

29. David Vickboons (I576-I629), Kermesse (I600) 


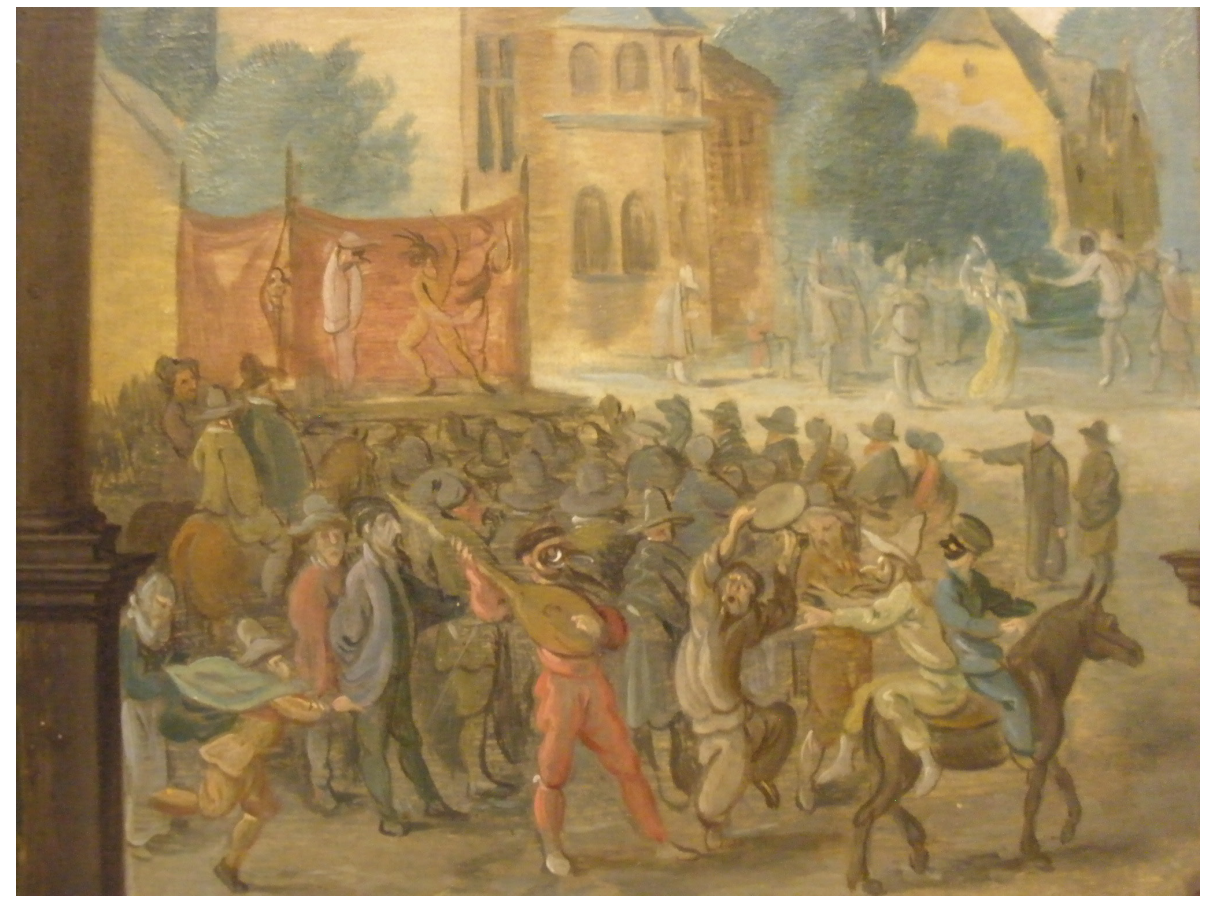

30. Jan Brueghel De Velours (I568-1625), Vanitat de la Vida Humana (c. I600). Detall d'espectacle de Commedia dell'Arte all'aperto, Galleria Sabauda (Torino).

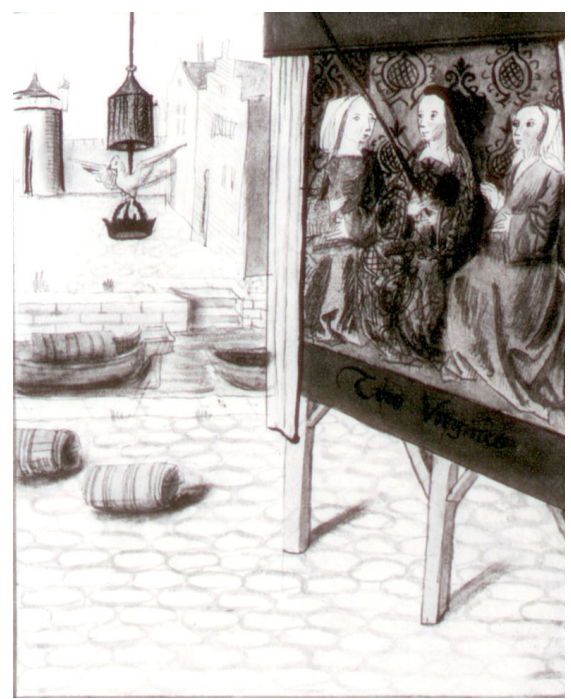

3I. Entrada de Joana d'Aragó a Brussel-les (I496): representació de les Tres Verges amb colom portador de corona, Kupferstichkabinett Berlin Ms 75 D 5, fol. 56. 